\title{
Which Hyperglycemic Model of Zebrafish (Danio rerio) Suites My Type 2 Diabetes Mellitus Research? A Scoring System for Available Methods
}

OPEN ACCESS

Edited by:

Liqing Zang,

Mie University, Japan

Reviewed by:

Carla Denise Bonan

Pontifical Catholic University of Rio

Grande Do Sul, Brazil

Massimo Mariotti,

University of Milan, Italy

*Correspondence:

Amin Tamadon

amintamaddon@yahoo.com

Yaser Tahamtan

yasertahamtani@royaninstitute.org

†These authors have contributed equally to this work and share first authorship

Specialty section

This article was submitted to Molecular Medicine,

a section of the journal Frontiers in Cell and Developmental Biology

Received: 11 January 2021 Accepted: 12 February 2021

Published: 15 March 2021

Citation:

Salehpour A, Rezaei M Khoradmehr A, Tahamtani $Y$ and Tamadon A (2021) Which Hyperglycemic Model of Zebrafish (Danio rerio) Suites My Type 2 Diabetes Mellitus Research? A

Scoring System for Available Methods. Front. Cell Dev. Biol. 9:652061. doi: 10.3389/fcell.2021.652061

\author{
Aria Salehpour ${ }^{1 \dagger}$, Mohammad Rezaei $^{2 \dagger}$, Arezoo Khoradmehr ${ }^{1}$, Yaser Tahamtani ${ }^{2,3,4 *}$ and \\ Amin Tamadon ${ }^{1,5 *}$
}

'The Persian Gulf Marine Biotechnology Research Center, The Persian Gulf Biomedical Sciences Research Institute, Bushehr University of Medical Sciences, Bandar Bushehr, Iran, ${ }^{2}$ Department of Diabetes, Obesity and Metabolism, Cell Science Research Center, Royan Institute for Stem Cell Biology and Technology, Academic Center for Education, Culture and Research, Tehran, Iran, ${ }^{3}$ Department of Stem Cells and Developmental Biology, Cell Science Research Center, Royan Institute for Stem Cell Biology and Technology, Academic Center for Education, Culture and Research, Tehran, Iran, ${ }^{4}$ Reproductive Epidemiology Research Center, Royan Institute for Reproductive Biomedicine, Academic Center for Education, Culture and Research, Tehran, Iran, ${ }^{5}$ Center of Marine Experimental and Comparative Medicine, The Persian Gulf Marine Biotechnology Research Center, The Persian Gulf Biomedical Sciences Research Institute, Bushehr University of Medical Sciences, Bandar Bushehr, Iran

Despite extensive studies on type 2 diabetes mellitus (T2DM), there is no definitive cure, drug, or prevention. Therefore, for developing new therapeutics, proper study models of T2DM is necessary to conduct further preclinical researches. Diabetes has been induced in animals using chemical, genetic, hormonal, antibody, viral, and surgical methods or a combination of them. Beside different approaches of diabetes induction, different animal species have been suggested. Although more than $85 \%$ of articles have proposed rat (genus Rattus) as the proper model for diabetes induction, zebrafish (Danio rerio) models of diabetes are being used more frequently in diabetes related studies. In this systematic review, we compare different aspects of available methods of inducing hyperglycemia referred as T2DM in zebrafish by utilizing a scoring system. Evaluating 26 approved models of T2DM in zebrafish, this scoring system may help researchers to compare different T2DM zebrafish models and select the best one regarding their own research theme. Eventually, glyoxalase1 (glo1-/-) knockout model of hyperglycemia achieved the highest score. In addition to assessment of hyperglycemic induction methods in zebrafish, eight most commonly proposed diabetic induction approval methods are suggested to help researchers confirm their subsequent proposed models.

Keywords: zebrafish, Danio rerio (zebrafish), diabetes mellitus, T2DM, hyperglycemia, animal modeling

\section{INTRODUCTION}

Zebrafish, nowadays known as a preferable animal model, was first introduced as an laboratory animal by Streisinger et al. (1981). They described zebrafish as a favorable model for developmental studies due to its transparency of embryo and remarkable fecundity (Streisinger et al., 1981; Grunwald and Streisinger, 1992). After a while, large-scale genetic studies demonstrated that zebrafish conserves ortholog genes which get disrupted in the state of illness similar to humans 
(Haffter et al., 1996; Barbazuk et al., 2000). In a short time, zebrafish converted to a frequent model of disease and drug discovery simultaneously with progression of genetic methods (Driever et al., 1996; Serbedzija et al., 1999; Dooley and Zon, 2000; Nasevicius and Ekker, 2000). It drew a lot of attention to be a proper model for metabolic diseases (Wang et al., 1998).

A variety of key features like resembling mammalian like pancreas specifications (Zon and Peterson, 2005), having main organ systems, such as a beating heart, mammalian like glucose regulation (Jurczyk et al., 2011), and similarity of nearly $70 \%$ of genes to human (Howe et al., 2013) make zebrafish superior in many scenarios. In addition, whole organ transcriptomic (Junker et al., 2014) and proteomic analyses (Nolte et al., 2015) are possible due to small size and in large scales due to laying capabilities of zebrafish. Zebrafish digestion system, adipose tissues, and skeletal muscle are physically humanlike (Schlegel and Stainier, 2007). Furthermore, blood circulation in vessels and neuronal and hormonal systems develop and become functional at early stages of development and make zebrafish favorable for early metabolic studies (Kimmel et al., 1995; Lakstygal et al., 2019; Pourghadamyari et al., 2019).

Scientists found it interesting to study type 2 diabetes mellitus (T2DM) in zebrafish as an animal model. T2DM is a very common metabolic disorder that can progress to other disorders, such as neurodegeneration (Sheikhpour and Khoradmehr, 2014; Farhadi et al., 2019). Scientists preferred utilizing rodents for preclinical studies of diabetes (Hajizadeh et al., 2014; HajizadehSaffar et al., 2015; Engel et al., 2019). Actually, more than 85\% of articles have used rat as their preferred model (Tripathi and Verma, 2014). So far, type 1 diabetes mellitus (T1DM), T2DM, and maturity-onset diabetes of the young (MODY) have been induced by a variety of methods in zebrafish (Zang et al., 2018).

Among the proposed methods, genetic methods may be more precise to target specific genes and produce abnormalities that are more accurate and more specific in results in comparison to other means. However, non-genetic ways of diabetes induction may be more available, cheaper, or easier to induce. In this systematic review, we aim to evaluate and compare all the available approaches for induction of hyperglycemia referred as T2DM in zebrafish. We used a comparison table in order to magnify the similarities and differences between the mentioned methods (Tables 1, 2). Also, scoring was suggested in order to choose the best model of hyperglycemia with the highest possible similarities to human among available ones (Tables 3,4 ) based on the previous scoring principles for animal modeling of polycystic ovary syndrome as a metabolic disease (Tamadon et al., 2018). A verity of criteria is considered as laboratory workmanship and biological resemblance to human T2DM state. It is also possible to confront different scores for each model due to further studies on these criteria in the future.

\section{MATERIALS AND METHODS}

\section{Software, Databases, and Search Queries}

We investigated four databases including Google scholar, PubMed/Medline, Microsoft academic, and Scopus. We used the following search query in titles for Google scholar, Microsoft academic, and Scopus databases: "(zebrafish OR danio) AND (diabetes OR diabetic OR hyperglycemia OR hyperglycemic OR glucose OR pancreas OR pancreatic OR insulin OR MODY)." For the PubMed/Medline database, we used "(zebrafish [Title/Abstract] OR danio [Title/Abstract]) AND (diabetes [Title/Abstract] OR diabetic [Title/Abstract] OR hyperglycemia [Title/Abstract] OR hyperglycemic [Title/Abstract])" search query to screen all related articles by title and abstract, simultaneously. Google scholar, Scopus, and Microsoft academic searches were performed using the Publish or Perish Windows software. Then, the PubMed/Medline results were added and duplicate results were removed using the Mendeley Desktop software (1,220 papers were found in general). We screened the remaining results by title and abstract to investigate available hyperglycemia models referred as T2DM in zebrafish. Publication date was not restricted.

\section{Inclusion and Exclusion Strategy}

We included the results of every study that was consistent with hyperglycemic outcome (whether fasting blood glucose elevation, post-high content diet feeding blood glucose elevation, postprandial glucose elevation, or whole larval glucose elevation) in the first place and have utilized one additional approval method which will be explained in detail further (section Methods of Model Verification). Selected articles are based on the induction of chronic hyperglycemia as T2DM occurs in human and without considering any publishing time limitations. We considered MODY studies too, because they manifest T2DM in the early stages of human life by involving well-known specific genes. Disruption of these genes increase the chance of T2DM occurrence. Therefore, they can be suitable subjects to study T2DM pathophysiology in animal models, too. We excluded every study with relation to T1DM induction methods. These studies consist of alloxan or streptozotocin (STZ) focused means of induction. Acute or non-persistent hyperglycemic states, such as glucose injection were disqualified too. During 2007 to 2020, based on the PubMed/Medline database, 270 research articles have been published on hyperglycemic model of zebrafish (Figure 1A). We selected 26 methodological papers of hyperglycemia referred as T2DM induction to be reviewed in our study, systematically (Figure 1B).

\section{Scoring Rationales and Principles}

The scoring system was obtained from the previous study by Tamadon et al. (2018). All the major diabetic outcomes in the proposed models are included and compared to human diabetic state, respectively. In the scoring tables (Tables 3, 4), any similarity between zebrafish and human diabetic state is graded as one positive score (marked as * in the table), any inconsistency with human diabetic state is graded as one negative score (marked as / in the table), and any unavailable data for the proposed factor is considered as zero or neutral (marked as \# in the table). Finally, all the scores of a single model are added up and the final score of the model is generated.

For a better comprehension and model selection for further studies, we separated all the scoring factors into two main categories; firstly, as the similarities to human and secondly, as 
TABLE 1 | Comparison of non-genetic induced hyperglycemia models referred as T2DM in zebrafish.

\begin{tabular}{|c|c|c|c|c|c|}
\hline Model/method & $\begin{array}{l}\text { Zebrafish life } \\
\text { stage }\end{array}$ & $\begin{array}{l}\text { Induction } \\
\text { time }\end{array}$ & Pros & Cons & References \\
\hline $\begin{array}{l}\text { Immersion alternatively in } 2 \text { and } 0 \% \\
\text { glucose solution model of hyperglycemia }\end{array}$ & $\begin{array}{l}\text { Adult ( } 1-3 \text { years } \\
\text { old) }\end{array}$ & 1 month & $\begin{array}{l}\text { - Simple } \\
\text { - Cheap } \\
\text { - Retinopathy }\end{array}$ & $\begin{array}{l}\text { - Needs continues } \\
\text { alteration of solution } \\
\text { - No investigation for insulin } \\
\text { resistance property }\end{array}$ & $\begin{array}{l}\text { Gleeson et al., } \\
2007\end{array}$ \\
\hline $\begin{array}{l}\text { Immersion in stepwise elevating glucose } \\
\text { concentration model of hyperglycemia }\end{array}$ & $\begin{array}{l}\text { Adult }(1-3 \\
\text { years } / 5-11 \\
\text { months })\end{array}$ & $\begin{array}{l}2 \text { month/10 } \\
\text { days }\end{array}$ & $\begin{array}{l}\text { - Simple } \\
\text { - Cheap } \\
\text { - Insulin resistance } \\
\text { - Anti-diabetic } \\
\text { drug responsiveness }\end{array}$ & - No significant drawback & $\begin{array}{l}\text { Connaughton } \\
\text { et al., } 2016\end{array}$ \\
\hline $\begin{array}{l}\text { Chronic immersion in } 110 \mathrm{mM} \text { glucose } \\
\text { solution model of hyperglycemia }\end{array}$ & $\begin{array}{l}\text { Adult stage } \\
(3-5 \mathrm{~cm})\end{array}$ & 14 days & $\begin{array}{l}\text { - Simple } \\
\text { - } \text { Cheap } \\
\text { - Fast* } \\
\text { - Persistent hyperglycemia } \\
\text { - } \text { Anti-diabetic drug } \\
\text { responsiveness } \\
\text { - Elevated glycated } \\
\text { - } \text { proteins } \\
\text { - Impaired insulin response }\end{array}$ & $\begin{array}{l}\text { - } 20 \% \text { mortality } \\
\text { - No investigation for insulin } \\
\text { resistance property }\end{array}$ & $\begin{array}{l}\text { Capiotti et al., } \\
2014\end{array}$ \\
\hline $\begin{array}{l}\text { Chronic immersion in } 4 \% \text { glucose solution } \\
\text { model of hyperglycemia }\end{array}$ & Adult & 28 days & $\begin{array}{l}\text { - Simple } \\
\text { - Cheap } \\
\text { - Retinal vasculopathy }\end{array}$ & $\begin{array}{l}\text { - Not suitable for female } \\
\text { zebrafish } \\
\text { - No investigation for insulin } \\
\text { resistance property }\end{array}$ & $\begin{array}{l}\text { Carnovali et al., } \\
2016\end{array}$ \\
\hline $\begin{array}{l}\text { Immersion in alternating } 4 \text { and } 5 \% \text { glucose } \\
\text { solution model of hyperglycemia }\end{array}$ & Larva & 5 days & $\begin{array}{l}\text { - Simple } \\
\text { - Cheap } \\
\text { - Fast } \\
\text { - Conserved retinopathic } \\
\text { symptoms until adulthood }\end{array}$ & $\begin{array}{l}\text { - High mortality } \\
\text { - No investigation for insulin } \\
\text { resistance property }\end{array}$ & Singh et al., 2019 \\
\hline $\begin{array}{l}\text { Immersion in } 130 \mathrm{mM} \text { glucose solution } \\
\text { model of elevated hyperglycemia }\end{array}$ & Larva & 3 days & $\begin{array}{l}\text { - Simple } \\
\text { - Cheap } \\
\text { - Fast } \\
\text { - Retinopathy }\end{array}$ & $\begin{array}{l}\text { - No investigation for insulin } \\
\text { resistance property }\end{array}$ & Jung et al., 2016 \\
\hline $\begin{array}{l}\text { Bisphenol } \mathrm{F} \text { induced model of } \\
\text { hyperglycemia }\end{array}$ & Larva & 2 days & $\begin{array}{l}\text { - Simple } \\
\text { - Cheap } \\
\text { - } \text { Fast } \\
\text { - Insulin resistance } \\
\text { - Larval stage } \\
\text { - Anti-diabetic } \\
\text { drug responsiveness }\end{array}$ & $\begin{array}{l}\text { - No significant changes to } \\
\text { glucagon } \\
\text { mRNA expressions }\end{array}$ & Zhao et al., 2018a \\
\hline $\begin{array}{l}\text { Bisphenol S induced model of } \\
\text { hyperglycemia }\end{array}$ & Adult (9 months) & 28 days & $\begin{array}{l}\text { - Simple } \\
\text { - Cheap } \\
\text { - Fast }\end{array}$ & - Not elevated insulin levels & Zhao et al., 2018b \\
\hline $\begin{array}{l}\text { Combined high cholesterol diet (HCD) and } \\
\text { high glucose }(\mathrm{HG} \text { ) environment model of } \\
\text { hyperglycemia for larval zebrafish }\end{array}$ & Larva & 10 days & $\begin{array}{l}\text { - Simple } \\
\text { - Cheap } \\
\text { - Fast } \\
\text { - Low mortality } \\
\text { - Increased insulin } \\
\text { - Increased glucagon } \\
\text { - Increased total cholesterol }\end{array}$ & - No significant drawback & Wang et al., 2013 \\
\hline $\begin{array}{l}\text { Combined high cholesterol diet (HCD) and } \\
\text { high glucose (HG) environment model of } \\
\text { hyperglycemia for adult zebrafish }\end{array}$ & Adult & 19 days & $\begin{array}{l}\text { - Simple } \\
\text { - Cheap }\end{array}$ & $\begin{array}{l}\text { - Not revealing insulin } \\
\text { resistance symptoms }\end{array}$ & Wang et al., 2020 \\
\hline
\end{tabular}

${ }^{*}$ We considered an induction time of up to two weeks as fast induction. 
TABLE 2 | Comparison of genetic induced hyperglycemia models referred as T2DM in zebrafish.

\begin{tabular}{|c|c|c|c|c|c|}
\hline Model/method & $\begin{array}{l}\text { Zebrafish life } \\
\text { stage }\end{array}$ & $\begin{array}{l}\text { Induction } \\
\text { time }\end{array}$ & Pros & Cons & References \\
\hline $\begin{array}{l}\text { Tg (acta1: dnIGF1R-EGFP) transgenic line } \\
\text { or zebrafish muscle insulin resistance } \\
\text { (zMIR) model of hyperglycemia }\end{array}$ & Adult & No time & $\begin{array}{l}\text { - Insulin resistance } \\
\text { - Increased } \beta \text {-cell } \\
\text { - Glucose intolerance }\end{array}$ & $\begin{array}{l}\text { - Long period for exhibiting } \\
\text { symptoms } \\
\text { - Not elevated FBS without } \\
\text { overfeeding } \\
\text { - Not increased number of } \\
\beta \text { cells in older group }\end{array}$ & $\begin{array}{l}\text { Maddison et al., } \\
2015\end{array}$ \\
\hline $\begin{array}{l}\text { FOXN3 [Tg(fapb10a:foxn3,EGFP)z106 and } \\
\text { Tg(fapb10a:FOXN3,EGFP)z107] models of } \\
\text { hyperglycemia }\end{array}$ & Larva/adult & No time & $\begin{array}{l}\text { - Stable hyperglycemia in } \\
\text { both larval stage } \\
\text { and adulthood }\end{array}$ & - No significant drawback & $\begin{array}{l}\text { Karanth et al., } \\
2016\end{array}$ \\
\hline $\begin{array}{l}\left.\text { K ATP gain of function (K } \mathrm{K}_{\text {ATP }}-\mathrm{GOF}\right) \text { model of } \\
\text { hyperglycemia }\end{array}$ & Larva/adult & No time & $\begin{array}{l}\text { - Severely hyperglycemic } \\
\text { - Increased } \\
\text { gluconeogenesis } \\
\text { - Decrease of glycolytic } \\
\text { genes } \\
\text { - Stable hyperglycemia in } \\
\text { both larval stage } \\
\text { and adulthood }\end{array}$ & - No significant drawback & $\begin{array}{l}\text { Emfinger et al., } \\
2019\end{array}$ \\
\hline $\begin{array}{l}\text { Type } 2 \text { deiodinase (DIO2) knockout model } \\
\text { of hyperglycemia }\end{array}$ & Adult & No time & $\begin{array}{l}\text { - Insulin resistance } \\
\text { - Similar enzymatic } \\
\text { regulations as human }\end{array}$ & $\begin{array}{l}\text { - Normoglycemia in older } \\
\text { group } \\
\text { - Not increased number of } \\
\beta \text { and } \alpha \text { cells }\end{array}$ & $\begin{array}{l}\text { Houbrechts et al., } \\
2019\end{array}$ \\
\hline $\begin{array}{l}\text { Multiplex conditional mutagenesis model } \\
\text { of hyperglycemia }\end{array}$ & Larva/adult & No time & $\begin{array}{l}\text { - Insulin resistance } \\
\text { - Post- } \\
\text { prandial hyperglycemia }\end{array}$ & - No significant drawback & $\begin{array}{l}\text { Maddison et al., } \\
2015\end{array}$ \\
\hline $\begin{array}{l}\text { Leptin receptor mutation model of } \\
\text { hyperglycemia }\end{array}$ & Larva/adult & No time & $\begin{array}{l}\text { - Increased insulin } \\
\text { - Increased glucagon } \\
\text { - Metformin responsiveness }\end{array}$ & $\begin{array}{l}\text { - Not } \\
\text { persistent hyperglycemia }\end{array}$ & Michel et al., 2016 \\
\hline $\begin{array}{l}\text { - Pdx1 gene knockout model of } \\
\text { hyperglycemia } \\
\text { - PDX1 gene knockdown model } \\
\text { of hyperglycemia }\end{array}$ & Larva/adult & No time & $\begin{array}{l}\text { - Retinopathic symptoms } \\
\text { - Post-prandial } \\
\text { hyperglycemia } \\
\text { - Susceptibility to high fat } \\
\text { diet } \\
\text { - Persistent hyperglycemia }\end{array}$ & $\begin{array}{l}\text { - Not revealing insulin } \\
\text { resistance, } \\
\text { decreased } \beta \text {-cells }\end{array}$ & $\begin{array}{l}\text { Kimmel et al., } \\
2015 \text {; } \\
\text { Wiggenhauser } \\
\text { et al., } 2020\end{array}$ \\
\hline $\begin{array}{l}\text { MODY gene mutation model of } \\
\text { hyperglycemia }\end{array}$ & Larva & No time & - Tolbutamide responsiveness & $\begin{array}{l}\text { - No investigation for insulin } \\
\text { resistance property }\end{array}$ & $\begin{array}{l}\text { Mathews and } \\
\text { Gustafsson, } 2019\end{array}$ \\
\hline $\begin{array}{l}\text { Aldh3a1 gene knockout model of } \\
\text { hyperglycemia }\end{array}$ & Larva & No time & $\begin{array}{l}\text { - } 4-\text { HNE elevation as } \\
\text { HbA1c elevation } \\
\text { - Retinopathy }\end{array}$ & $\begin{array}{l}\text { - No investigation for insulin } \\
\text { resistance property }\end{array}$ & Lou et al., 2020 \\
\hline $\begin{array}{l}\text { G protein-coupled receptor } 27 \text { (Gpr27) } \\
\text { knockout model of hyperglycemia }\end{array}$ & Larva & No time & $\begin{array}{l}\text { - } \text { Post-prandial } \\
\text { hyperglycemia } \\
\text { - Insulin resistance } \\
\text { - Metformin responsiveness }\end{array}$ & - No significant drawback & Nath et al., 2020 \\
\hline $\begin{array}{l}\text { Glyoxalase1 }\left(\mathrm{glo1}^{-/-}\right) \text {knockout model of } \\
\text { hyperglycemia }\end{array}$ & Larva/adult & No time & $\begin{array}{l}\text { - Increased post-prandial } \\
\text { glucose } \\
\text { - Insulin resistance } \\
\text { symptoms } \\
\text { - Impaired glucose } \\
\text { tolerance } \\
\text { - Retinopathy } \\
\text { - Persistent susceptibility to } \\
\text { high fat diet from larval to } \\
\text { adult stage }\end{array}$ & $\begin{array}{l}\text { - } \text { Not persistent } \\
\text { hyperglycemia } \\
\text { - No direct insulin } \\
\text { resistance assay (just } \\
\text { p70-S6 kinase } \\
\text { activation upregulation) }\end{array}$ & Lodd et al., 2019 \\
\hline $\begin{array}{l}\text { Glucose transporter } 12 \text { (GLUT12) deficient } \\
\text { model of hyperglycemia }\end{array}$ & Larva & No time & $\begin{array}{l}\text { - Insulin resistance } \\
\text { - Metformin responsiveness }\end{array}$ & - No significant drawback & $\begin{array}{l}\text { Jiménez-Amilburu } \\
\text { et al., } 2015\end{array}$ \\
\hline $\begin{array}{l}\text { Single insra or insrb knockout model of } \\
\text { hyperglycemia }\end{array}$ & Larva & No time & $\begin{array}{l}\text { - Post-prandial } \\
\text { hyperglycemia } \\
\text { - Insulin resistance }\end{array}$ & - No significant drawback & Yang et al., 2018 \\
\hline
\end{tabular}


TABLE 3 | Scoring of non-genetic induced hyperglycemia models referred as T2DM in zebrafish.

\begin{tabular}{|c|c|c|c|c|c|c|c|c|c|c|c|c|c|}
\hline \multirow{2}{*}{$\begin{array}{l}\text { Phenotype } \\
\text { Model/method }\end{array}$} & \multirow{2}{*}{$\begin{array}{c}\begin{array}{c}\text { Human } \\
\text { disorder }\end{array} \\
\text { NA }\end{array}$} & \multicolumn{6}{|c|}{ Glucose induced models } & \multicolumn{2}{|c|}{ Diet induced models } & \multicolumn{2}{|c|}{ Chemical induced model } & \multicolumn{2}{|c|}{ Hybrid models } \\
\hline & & $\begin{array}{c}\text { Immersion } \\
\text { alternatively in } \\
2 \text { and } 0 \% \\
\text { glucose } \\
\text { solution model } \\
\text { of } \\
\text { hyperglycemia }\end{array}$ & $\begin{array}{l}\text { Immersion in } \\
\text { stepwise } \\
\text { elevating } \\
\text { glucose } \\
\text { concentration } \\
\text { model of } \\
\text { hyperglycemia }\end{array}$ & $\begin{array}{c}\text { Chronic } \\
\text { immersion in } \\
110 \mathrm{mM} \\
\text { glucose } \\
\text { solution model } \\
\text { of } \\
\text { hyperglycemia }\end{array}$ & $\begin{array}{c}\text { Chronic } \\
\text { immersion in } \\
4 \% \text { glucose } \\
\text { solution model } \\
\text { of } \\
\text { hyperglycemia }\end{array}$ & $\begin{array}{l}\text { Immersion in } \\
\text { alternating } 4 \\
\text { and } 5 \% \\
\text { glucose } \\
\text { solution model } \\
\text { of } \\
\text { hyperglycemia }\end{array}$ & $\begin{array}{l}\text { Immersion in } \\
130 \mathrm{mM} \\
\text { glucose } \\
\text { solution model } \\
\text { of elevated } \\
\text { hyperglycemi }\end{array}$ & $\begin{array}{l}\text { Obesity model } \\
\text { of } \\
\text { hyperglycemia }\end{array}$ & $\begin{array}{c}\text { High fat diet } \\
\text { (HFD) } \\
\text { containing 1\% } \\
\text { egg yolk model } \\
\text { of } \\
\text { hyperglycemia }\end{array}$ & $\begin{array}{c}\text { Bisphenol F } \\
\text { induced model } \\
\text { of } \\
\text { hyperglycemia }\end{array}$ & $\begin{array}{c}\text { Bisphenol S } \\
\text { induced model } \\
\text { of } \\
\text { hyperglycemia }\end{array}$ & $\begin{array}{c}\text { Combined high } \\
\text { cholesterol diet } \\
\text { (HCD) and high } \\
\text { glucose (HG) } \\
\text { environment } \\
\text { model of } \\
\text { hyperglycemia } \\
\text { for larval } \\
\text { zebrafish }\end{array}$ & $\begin{array}{c}\text { Combined high } \\
\text { cholesterol diet } \\
\text { (HCD) and high } \\
\text { glucose (HG) } \\
\text { environment } \\
\text { model of } \\
\text { hyperglycemia } \\
\text { for adult } \\
\text { zebrafish }\end{array}$ \\
\hline References & $\begin{array}{c}\text { Cox and } \\
\text { Edelman, } 2009\end{array}$ & $\begin{array}{c}\text { Gleeson et al., } \\
2007\end{array}$ & $\begin{array}{l}\text { Connaughton } \\
\text { et al., 2016; } \\
\text { Mohammadi } \\
\text { et al., } 2020\end{array}$ & $\begin{array}{l}\text { Capiotti et al., } \\
2014\end{array}$ & $\begin{array}{l}\text { Carnovali } \\
\text { et al., } 2016\end{array}$ & $\begin{array}{l}\text { Singh et al., } \\
2019\end{array}$ & $\begin{array}{l}\text { Jung et al., } \\
2016\end{array}$ & $\begin{array}{l}\text { Zang et al., } \\
2017\end{array}$ & $\begin{array}{l}\text { Meng et al., } \\
2017\end{array}$ & $\begin{array}{c}\text { Zhao et al., } \\
2018 a\end{array}$ & $\begin{array}{l}\text { Zhao et al., } \\
\text { 2018b }\end{array}$ & $\begin{array}{l}\text { Wang et al., } \\
2013\end{array}$ & $\begin{array}{l}\text { Wang et al., } \\
2020\end{array}$ \\
\hline \multicolumn{14}{|c|}{ SIMILARITIES TO HUMAN } \\
\hline $\begin{array}{l}\text { Hyperglycemic } \\
\text { outcome }\end{array}$ & * & * & * & * & * & * & * & * & * & * & * & * & * \\
\hline Impaired $\mathrm{GT}^{\dagger}$ & * & $\#$ & $\#$ & $\#$ & $\#$ & \# & \# & * & \# & $\#$ & $\#$ & $\#$ & $\#$ \\
\hline $\begin{array}{l}\mathrm{HbA1c} \\
\text { alternatives } \\
\text { assay }\end{array}$ & * & \# & \# & * & \# & \# & \# & \# & \# & \# & \# & \# & \# \\
\hline Retinopathy & * & * & $\#$ & $\#$ & * & * & * & $\#$ & $\#$ & $\#$ & $\#$ & $\#$ & \# \\
\hline $\begin{array}{l}\text { Insulin } \\
\text { resistance }\end{array}$ & * & $\#$ & * & $\#$ & $\#$ & $\#$ & $\#$ & * & * & * & / & * & / \\
\hline $\begin{array}{l}\text { Anti-diabetic } \\
\text { drug } \\
\text { responsiveness }\end{array}$ & * & * & * & * & \# & $\#$ & $\#$ & * & $\#$ & * & $\#$ & * & $\#$ \\
\hline $\begin{array}{l}\text { Stable } \\
\text { hyperglycemia }\end{array}$ & * & $\#$ & $\#$ & $*(7 D)$ & $\#$ & $\#$ & $\#$ & ${ }^{*}(1 \mathrm{M})$ & $\#$ & $\#$ & $\#$ & $\#$ & $\#$ \\
\hline Total score & 7 & 3 & 3 & 4 & 2 & 2 & 2 & 5 & 2 & 3 & 0 & 3 & 0 \\
\hline \multicolumn{14}{|c|}{ SUITABILITY AS A MODEL } \\
\hline $\begin{array}{l}\text { Larval or } \\
\text { embryonic } \\
\text { stage }\end{array}$ & * & / & $\#$ & / & / & * & * & $\#$ & $\#$ & * & $\#$ & * & $\#$ \\
\hline Adult stage & * & * & * & * & * & $\#$ & $\#$ & * & * & $\#$ & * & $\#$ & * \\
\hline Induction time ${ }^{\ddagger}$ & * & $*(1 \mathrm{M})$ & ${ }^{*}(2 \mathrm{M} / 10 \mathrm{D})$ & $*(14 \mathrm{D})$ & $*(1 \mathrm{M})$ & $*(5 \mathrm{D})$ & ${ }^{*}(3 \mathrm{D})$ & ${ }^{*}(7 \mathrm{D})$ & $/(2.5 \mathrm{M})$ & *(2D) & ${ }^{\star}(28 \mathrm{D})$ & ${ }^{*}(10 \mathrm{~d})$ & ${ }^{*}(19 d)$ \\
\hline Total score & 3 & 1 & 2 & 1 & 1 & 2 & 2 & 2 & 0 & 2 & 2 & 2 & 2 \\
\hline Model score & 10 & 4 & 5 & 5 & 3 & 4 & 4 & 7 & 2 & 5 & 2 & 5 & 2 \\
\hline
\end{tabular}

${ }^{\dagger} G T$, Glucose tolerance; D, Day; M, Month.

*: Positive score $=+1$.

/: Negative score $=-1$.

\#: No information available $=0$.

FScoring of induction time: $0-30$ days $=+1$; more than 30 days $=-1$. 
TABLE 4 | Scoring of genetic induced hyperglycemia models referred as T2DM in zebrafish.

\begin{tabular}{|c|c|c|c|c|c|c|c|c|c|c|c|c|c|c|}
\hline \multirow{2}{*}{$\begin{array}{l}\text { Phenotype } \\
\text { Model/method }\end{array}$} & \multirow{2}{*}{$\begin{array}{c}\begin{array}{c}\text { Human } \\
\text { disorder }\end{array} \\
\text { NA }\end{array}$} & \multicolumn{13}{|c|}{ Genetic models } \\
\hline & & $\begin{array}{c}\text { Tg (acta1: } \\
\text { dnIGF1R-EGFP) } \\
\text { transgenic line or } \\
\text { zebrafish muscle } \\
\text { insulin resistance } \\
\text { (zMIR) model of } \\
\text { hyperglycemia }\end{array}$ & $\begin{array}{c}\text { FOXN3 } \\
\text { [Tg(fapb10a: } \\
\text { foxn3,EGFP) } \\
\text { z106 and } \\
\text { Tg(fapb10a: } \\
\text { FOXN3,EGFP) } \\
\text { z107] models } \\
\text { of } \\
\text { hyperglycemia }\end{array}$ & $\begin{array}{l}\text { KATP gain of } \\
\text { function } \\
\text { (KATP-GOF) } \\
\text { model of } \\
\text { hyperglycemia }\end{array}$ & $\begin{array}{c}\text { Type 2 } \\
\text { deiodinase } \\
\text { (DIO2) } \\
\text { knockout } \\
\text { model of } \\
\text { hyperglycemia }\end{array}$ & $\begin{array}{l}\text { Multiplex } \\
\text { conditional } \\
\text { mutagenesis } \\
\text { model of } \\
\text { hyperglycemia }\end{array}$ & $\begin{array}{l}\text { Leptin receptor } \\
\text { mutation } \\
\text { model of } \\
\text { hyperglycemia }\end{array}$ & $\begin{array}{l}\text { Pdx1 gene } \\
\text { knockout } \\
\text { model of } \\
\text { hyperglycemia } \\
\text { PDX1 gene } \\
\text { knockdown } \\
\text { model } \\
\text { of hyperglycemia }\end{array}$ & $\begin{array}{l}\text { MODY gene } \\
\text { mutation } \\
\text { model of } \\
\text { hyperglycemia } \\
\text { ia }\end{array}$ & $\begin{array}{l}\text { Aldh3a1 gene } \\
\text { knockout } \\
\text { model of } \\
\text { hyperglycemia }\end{array}$ & $\begin{array}{l}\text { G protein- } \\
\text { coupled } \\
\text { receptor } 27 \\
\text { (Gpr27) } \\
\text { knockout } \\
\text { model of } \\
\text { hyperglycemia }\end{array}$ & $\begin{array}{l}\text { Glyoxalase 1 } \\
\left(\text { glo } 1^{-1-}\right) \\
\text { knockout } \\
\text { model of } \\
\text { hyperglycemia }\end{array}$ & $\begin{array}{c}\text { Glucose } \\
\text { transporter } 12 \mathrm{i} \\
\text { (GLUT12) } \\
\text { deficient model } \\
\text { of } \\
\text { hyperglycemia }\end{array}$ & $\begin{array}{l}\text { Single insra or } \\
\text { insrb knockout } \\
\text { model of } \\
\text { I hyperglycemia }\end{array}$ \\
\hline References & $\begin{array}{l}\text { Cox and } \\
\text { Edelman, } \\
2009\end{array}$ & $\begin{array}{l}\text { Maddison et al., } \\
2015\end{array}$ & $\begin{array}{l}\text { Karanth et al., } \\
2016\end{array}$ & $\begin{array}{l}\text { Emfinger et al., } \\
2019\end{array}$ & $\begin{array}{l}\text { Houbrechts } \\
\text { et al., } 2019\end{array}$ & Yin et al., 2015 & $\begin{array}{l}\text { Michel et al., } \\
2016\end{array}$ & $\begin{array}{l}\text { Kimmel et al., } \\
2015 ; \\
\text { Wiggenhauser } \\
\text { et al., } 2020\end{array}$ & $\begin{array}{c}\text { Mathews and } \\
\text { Gustafsson, } \\
2019\end{array}$ & $\begin{array}{l}\text { Lou et al., } \\
2020\end{array}$ & $\begin{array}{l}\text { Nath et al., } \\
2020\end{array}$ & $\begin{array}{l}\text { Lodd et al., } \\
2019\end{array}$ & $\begin{array}{l}\text { Jiménez- } \\
\text { Amilburu et al., } \\
2015\end{array}$ & $\begin{array}{l}\text { Yang et al., } \\
2018\end{array}$ \\
\hline \multicolumn{15}{|c|}{ SIMILARITIES TO HUMAN } \\
\hline $\begin{array}{l}\text { Hyperglycemic } \\
\text { outcome }\end{array}$ & * & * & * & * & * & * & * & * & * & * & * & * & * & * \\
\hline Impaired $\mathrm{GT}^{\dagger}$ & * & * & $\#$ & \# & $\#$ & * & / & * & \# & $\#$ & * & * & $\#$ & * \\
\hline $\begin{array}{l}\mathrm{HbA1c} \\
\text { alternatives } \\
\text { assay }\end{array}$ & * & \# & $\#$ & $\#$ & $\#$ & $\#$ & $\#$ & $\#$ & $\#$ & * & $\#$ & * & $\#$ & $\#$ \\
\hline Retinopathy & * & \# & $\#$ & $\#$ & \# & * & $\#$ & * & \# & * & $\#$ & * & $\#$ & $\#$ \\
\hline $\begin{array}{l}\text { Insulin } \\
\text { resistance }\end{array}$ & * & * & \# & \# & * & * & * & \# & \# & \# & * & * & * & * \\
\hline $\begin{array}{l}\text { Anti-diabetic } \\
\text { drug } \\
\text { responsiveness }\end{array}$ & * & $\#$ & $\#$ & $\#$ & \# & \# & * & * & * & $\#$ & * & $\#$ & * & $\#$ \\
\hline $\begin{array}{l}\text { Stable } \\
\text { hyperglycemia }\end{array}$ & * & * & * & * & * & * & / & * & \# & \# & \# & * & \# & \# \\
\hline Total score & 7 & 4 & 2 & 2 & 3 & 5 & 1 & 5 & 2 & 3 & 4 & 6 & 3 & 3 \\
\hline \multicolumn{15}{|c|}{ SUITABILITY AS A MODEL } \\
\hline $\begin{array}{l}\text { Larval or } \\
\text { embryonic } \\
\text { stage }\end{array}$ & * & \# & * & * & \# & * & * & * & * & * & * & * & * & * \\
\hline Adult stage & * & * & * & * & * & \# & * & * & \# & \# & \# & * & \# & \# \\
\hline Induction time $\mathrm{e}^{\ddagger}$ & * & ${ }^{*}(0)$ & ${ }^{*}(0)$ & ${ }^{*}(0)$ & ${ }^{*}(0)$ & ${ }^{*}(0)$ & ${ }^{*}(0)$ & ${ }^{*}(0)$ & ${ }^{*}(0)$ & ${ }^{*}(0)$ & ${ }^{*}(0)$ & ${ }^{*}(0)$ & ${ }^{\star}(0)$ & ${ }^{*}(0)$ \\
\hline Total score & 3 & 2 & 3 & 3 & 2 & 2 & 3 & 3 & 2 & 2 & 2 & * & 2 & 2 \\
\hline Model score & 10 & 6 & 5 & 5 & 5 & 7 & 4 & 8 & 4 & 5 & 6 & 9 & 5 & 5 \\
\hline
\end{tabular}

${ }^{\dagger} G T$, Glucose tolerance; D, Day; M, Month.

*: Positive score $=+1$.

/: Negative score $=-1$.

\#: No information available $=0$.

FScoring of induction time: $0-30$ days $=+1$; more than 30 days $=-1$. 


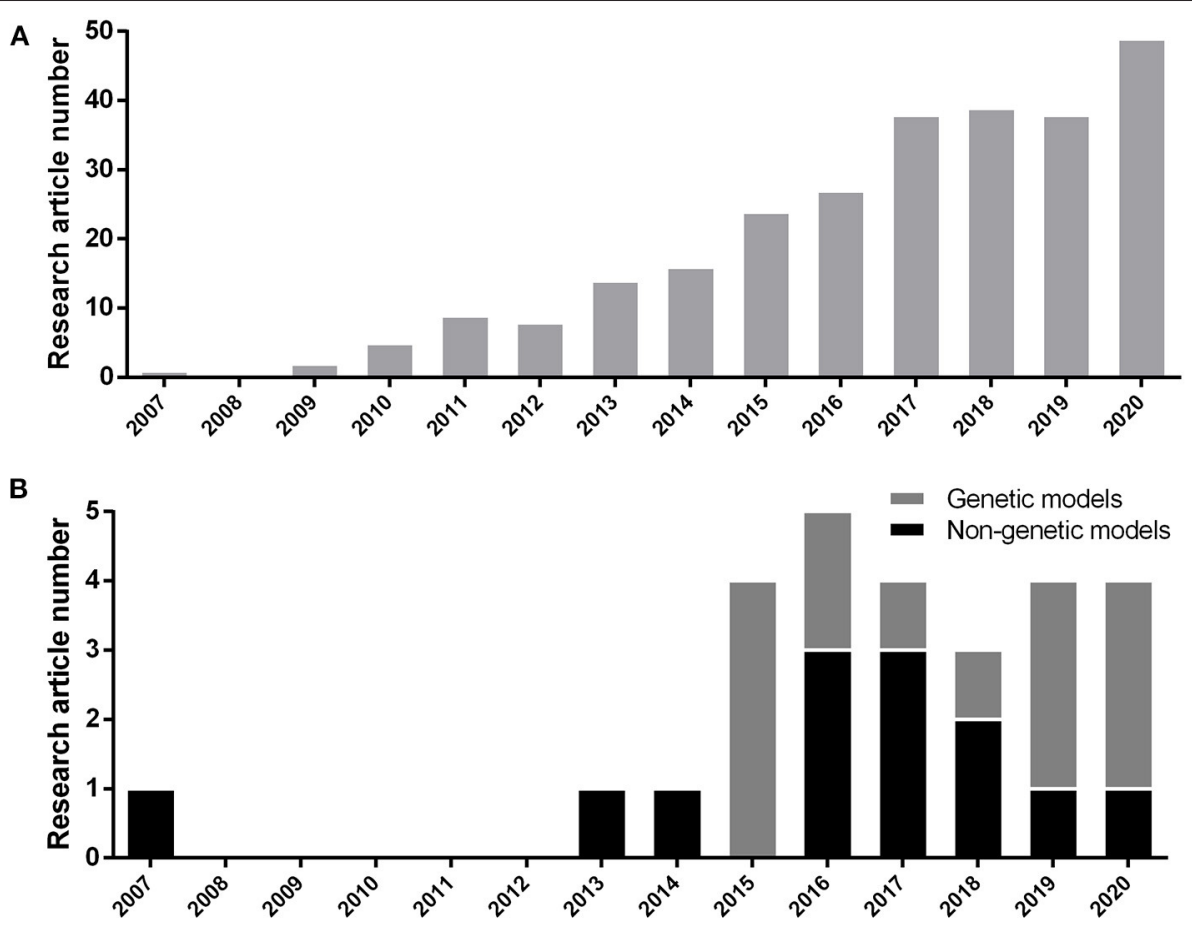

FIGURE 1 | (A) Number of research article publications by year to demonstrate the growing interest of researchers by hyperglycemic model of zebrafish (Danio rerio) based on the PubMed/Medline database. (B) Development of new genetic or non-genetic hyperglycemic model of zebrafish (Danio rerio) by year.

the suitability of the model. All the factors for human scoring are regarded as one positive score and all the suitability factors are considered to be met by the perfect model (score of 10). Therefore, the highest grade is achieved in the first column of the table (human disorder). All the verified models are included in the table and evaluated in proportion to the ideal model (first column).

All available models can be categorized as larval or adult stage zebrafish models. It wholly depends on the researcher's intention to find the most suitable model considering their own purposes, research theme, limitations, and circumstances. We considered a one plus score for the availability of the model in both zebrafish life stages. As we can see, some models can be utilized in both larval and adult stages, receiving a higher score. Induction time can be a crucial factor. Therefore, we considered a positive score for faster induction time ( $<1$ month) due to faster results, higher efficiency of the model, and workmanship and deducted a score for more induction time. As we can see, genetic models are ahead in terms of time saving factor (0 days for induction).

\section{METHODS/MODELS OF INDUCING HYPERGLYCEMIA IN ZEBRAFISH}

\section{Glucose Based Methods of Inducing Hyperglycemia}

Due to the ease of induction and cheapness, glucose-based induction is favorable. There are different protocols which have been developed based on matter of time, life stage, and glucose concentration. We can consider this approach of T2DM induction in zebrafish as the first approach ever, which is modified and has evolved over years.

\section{Immersion Alternatively in 2\% and 0\% Glucose Solution Model of Hyperglycemia}

Gleeson et al. (2007) introduced a primary method of inducing T2DM in zebrafish. In this method, zebrafish were alternately exposed to $2 \%$ glucose and $0 \%$ glucose solution for 30 days. Common diabetes symptoms, such as retinopathy and increased fasting blood glucose (FBS) levels were observed afterwards. The FBS for control groups of wild-type zebrafish were measured 74 \pm 8.5 and $89 \pm 10.6 \mathrm{mg} / \mathrm{dL}$ for AB type. The FBS passed 200 $\mathrm{mg} / \mathrm{dL}$ (three times more the normal state) after 30 days.

\section{Immersion in Stepwise Elevating Glucose Concentration Model of Hyperglycemia}

Connaughton et al. (2016) exhibited that the previous method is age-dependent. In this article, two groups of zebrafish (1-3 years old) and (4-11 months old) were investigated. Initially, both groups were immersed in 2 and $0 \%$ alternating glucose solution for 2 months (as mentioned in the Immersion Alternatively in 2 and $0 \%$ Glucose Solution Model of Hyperglycemia method). In the older group, high blood glucose levels were observed for the entire 2 months, but the younger fish group temporarily gained higher glucose levels (up to first month) and then adopted to the new environment and returned to the normoglycemic state. To solve this challenge, they modified the protocol and exerted an alternative method so that the concentration of glucose was 
elevating within the progress of induction stages. Initially, they incubated the younger zebrafish in $1 \%$ glucose solutions for 2 weeks. They increased glucose concentration up to $2 \%$ in the next 2 weeks and after that, incubated the young adult zebrafish in $3 \%$ glucose solution for the next month. The younger group of zebrafish gained a stable hyperglycemia state for the entire 2 months of induction.

In another study by Mohammadi et al. (2020), they used the same approach in a much shorter time. They incubated the adult zebrafish for 4 days in $50 \mathrm{mM}$ glucose solution, followed by $100 \mathrm{mM}$ glucose concentration immersion for the next 3 days. Finally, they elevated the glucose concentration to $200 \mathrm{mM}$ for the last 3 days ( 10 days total). They showed that their approach is in compliance with previous study by revealing higher glucose concentrations and being responsive to metformin as an antidiabetic drug (Mohammadi et al., 2020).

\section{Chronic Immersion in 110 mM Glucose Solution Model of Hyperglycemia}

Capiotti et al. (2014) introduced another method of inducing diabetic symptoms. Initially, three concentrations of 55,110 , and $166 \mathrm{mM}$ of glucose solution were investigated. Due to the lower mortality rate of fish compared to the other two concentrations, they chose $110 \mathrm{mM}$ concentrations for induction. In a 5-l tank containing $110 \mathrm{mM}$ glucose, 15 zebrafish were incubated for 14 days. After 14 days, blood glucose levels increased up to four or five times in comparison to the control group. To assess the stability of this process, the zebrafish were placed in fresh water for 7 days. Measurements showed that blood glucose was still higher than the control group. By assessing fructosamine as an indicator of non-enzymatic glycation of proteins from the eyes of the zebrafish, they noticed elevated levels of fructosamine in the test group and even in the group that had been isolated for 7 days in fresh water, which confirms the reliability of the procedure. Therapies with anti-diabetic drugs, such as glimepiride and metformin were applied, which represent two different mechanisms of therapeutic. Short induction time as well as stability of hyperglycemic status are both prominent advantages of this method (Capiotti et al., 2014).

\section{Chronic Immersion in 4\% Glucose Solution Model of Hyperglycemia}

Carnovali et al. (2016) used a different approach of chronic immersion in glucose solution. In this study, $4 \%$ glucose solution was used for 28 continuous days in order to induce hyperglycemia. This method also revealed insulin resistance and retinal vasculopathy as a result.

\section{Immersion in Alternating 4\% and 5\% Glucose Solution Model of Hyperglycemia}

In order to produce hyperglycemic state, Singh et al. (2019) used 4 and 5\% alternating glucose solution individually from $3 \mathrm{~h}$ postfertilization (hpf) to 5 days' post-fertilization (dpf). This means that the induction resulted in an increased total free glucose and retinopathic symptoms that were conserved up to adulthood. They also suggested that this induction method mimics fetus condition in mothers with pre-existing and gestational diabetes.
It is worth mentioning that alternating immersion of zebrafish in 4 and $5 \%$ glucose solution caused 28.4 and $37.5 \%$ of mortality rate, accordingly.

\section{Immersion in $130 \mathrm{mM}$ Glucose Solution Model of Elevated Hyperglycemia}

Another glucose based approach of hyperglycemia induction that Jung et al. (2016) utilized was the immersion in $130 \mathrm{mM}$ glucose solution from 3 to $6 \mathrm{dpf}$. The approach showed to be effective by the elevation of the whole larval glucose and showing retinopathic symptoms, such as thickening of the vascular basement membrane and increased vascular permeability (Robinson et al., 2012).

\section{Diet Based Methods of Inducing Hyperglycemia}

Improper diet, overweight, or obesity are proved to be major reasons of diabetes occurrence ( $\mathrm{Hu}$ et al., 2001). Zebrafish is considered to be a suitable model due to possessing major organs with high resemblance to human counterparts, such as kidney, pancreas, adipose tissue, and skeletal muscle (Schlegel and Stainier, 2007). This method can be considered as one of the most effective and most accessible ways to exhibit hyperglycemic state in zebrafish. It is worth mentioning diet based method of producing T2DM in zebrafish was inspired from rodents obesity and insulin resistance model (Tobey et al., 1982; Surwit et al., 1988).

\section{Obesity Model of Hyperglycemia}

Interestingly, $90 \%$ of people with T2DM are overweight or obese. Therefore, there would be observations of diabetic symptoms by inducing obesity (Scherer, 2006). Zebrafish has exhibited conserved pathophysiological pathways with mammalian obesity (Oka et al., 2010). In a study by Zang et al. (2017), these principles were utilized to produce hyperglycemic condition in zebrafish. Zebrafish were fed Otohime B2 six times a day for 8 weeks (408 calories for the test group and 68 calories for the control group). FBS level showed a significant increase compared to the control group by the first week and kept the hyperglycemic state constant throughout the procedure. Up to 4 weeks after stopping treatment, despite a slight decrease, FBS remained higher than in the control group. They also used the anti-diabetic drug responsiveness test, glucose tolerance test, and deep RNA sequencing in order to verify this model. This method can be considered as the most available approach to study diabetes utilizing zebrafish.

\section{High Fat Diet (HFD) Containing 1\% Egg Yolk Model of Hyperglycemia}

In another study by Meng et al. (2017), they utilized HFD consisted of brine shrimp and $1 \%$ egg yolk for 10 weeks, and the results were consistent with the previous obesity induced hyperglycemia method. They revealed that insulin receptor substrate 2 (IRS2) and glucose transporter 2 (GLUT2) were significantly decreased in livers of HFD-treated zebrafish and insulin levels were elevated in the muscle and liver tissue significantly suggesting insulin resistance induction. 


\section{Chemical Based Methods of Inducing Hyperglycemia}

Etiology of diabetes has been pursued over years. Different chemicals that may be diabetogenic have surrounded us by different doses or exposure period. Chemicals, such as alloxan and streptozotocin are widely used to induce diabetes in rodents (Engel et al., 2019). In two studies, effects of bisphenol compounds as common chemicals on glucose metabolism of zebrafish have been investigated.

\section{Bisphenol F Induced Model of Hyperglycemia}

Zhao et al. (2018a) showed the effects of bisphenol F on glucose homeostasis in zebrafish larvae. Background of this study had exhibited insulin resistance, decreased glucose tolerance, and higher levels of plasma insulin, triglycerides, and leptin in mice. In this study, larval zebrafish was exposed to different doses of bisphenol F, but only 10 and $100 \mu \mathrm{g} / \mathrm{L}$ concentrations showed diabetic symptoms like increased levels of insulin and decreased transcription levels of genes which encode insulin receptor substrate. They also showed an increase in mRNA transcription of key gluconeogenesis enzymes. Insulin levels increased and transcription levels of genes encoding insulin receptor substrates decreased significantly suggesting insulin resistance. All these signs imply to look at this model as a qualified approach.

\section{Bisphenol S Induced Model of Hyperglycemia}

Another study by Zhao et al. (2018b) revealed that bisphenol $\mathrm{S}$ also generates a diabetic state. Exposure to 1 and $10 \mu \mathrm{g} / \mathrm{L}$ of bisphenol S significantly increased FBS levels. In spite of insulin levels reduction, gluconeogenesis and glycogenolysis in the liver were promoted, glycogen production in the liver and muscle and glycolysis in the muscle were inhibited (Zhao et al., 2018b). These clues show that bisphenol $\mathrm{S}$ is likely to be a diabetogenic agent in zebrafish.

\section{Hybrid Based Methods of Inducing Hyperglycemia}

It is also recommended to use a combination of available methods in order to develop a more consistent condition to human diabetes. This approach was also inspired by rodents' studies. Combination of techniques can be promising to develop solid models (Kurup and Bhonde, 2000; Pinhas-Hamiel and Zeitler, 2005; Zhang et al., 2008).

\section{Combined High Cholesterol Diet (HCD) and High Glucose (HG) Environment Model of Hyperglycemia for Larval Zebrafish}

Wang et al. (2013) developed a hybrid method so that a HCD (10\% cholesterol) was used and fish were exposed to HG (2\% glucose) solution, simultaneously similar to some methods used for mice. This method created a manifestation of diabetes by causing vascular disorders. Wild type zebrafish and various transgenic lines have been used in this study. The levels of insulin, glucagon, glucose, triglyceride, and cholesterol increased significantly. The model was responsive to anti-diabetic drugs, such as metformin and pioglitazone (Wang et al., 2013).

\section{Combined High Cholesterol Diet (HCD) and High Glucose (HG) Environment Model of Hyperglycemia for Adult Zebrafish}

In another study, Wang et al. (2020) revealed that exposure to 2\% glucose solution and consuming $10 \%$ cholesterol diet for 19 days induces hyperglycemic state in adult zebrafish. They measured various parameters to achieve a better comprehension of hyperglycemic state related inflammation and apoptosis. While glucose and glucagon levels increased considerably, expression increase of insulin and insulin receptor mRNAs were not significant. These studies reveal that the hybrid approach (HCD$\mathrm{HG}$ ) of producing hyperglycemic state in zebrafish exhibits symptoms that are more accurate while exploited in earlier stages of zebrafish life.

\section{Genetic Based Methods of Inducing Hyperglycemia}

Genetic manipulation of animals is widely used for a verity of scenarios. Using genetic disease modeling in zebrafish is getting more and more desirable by researchers (Phillips and Westerfield, 2019). Techniques, such as Tol2 (Kwan et al., 2007), clustered regularly interspersed short palindromic repeats (CRISPR) (Cong et al., 2013; Qi et al., 2013), zinc finger nuclease (ZFN) (Doyon et al., 2008), morpholino injection (Partridge et al., 1996), and TALEN (Miller et al., 2011) based methods are popular in generation of a hyperglycemic state.

\section{Zebrafish Tol2 Models of T2DM}

Tg (acta1: dnIGF1R-EGFP) Transgenic Line or Zebrafish Muscle Insulin Resistance (zMIR) Model of Hyperglycemia Maddison et al. (2015) made zebrafish insulin resistant by expressing dominant-negative insulin growth factor (IGF) in skeletal muscle that led to $\beta$-cell dysfunction, too. These zebrafish showed insulin-signaling disorders, which is similar to the symptoms of T2DM in humans. It was initially associated with an increase in the number of pancreatic $\beta$-cells up to the first 6 months (in order to compensate for insulin resistance), which maintained a normal blood glucose. Then, the number of $\beta$-cells decreased and got equal to the control group at the end of the first year. Overfeeding was followed by glucose intolerance and an increase in FBS, which indicated pancreatic $\beta$-cell vulnerability similar to the symptoms of T2DM. Glucose intolerance progress was slow and there was no change in FBS without over nutrition (Maddison et al., 2015). Long time to exhibit symptoms is the major drawback of this method, but remarkable stability and similarity to the human model are major advantages.

\section{FOXN3 [Tg(fapb10a:foxn3,EGFP)z106 and}

$\mathrm{Tg}($ fapb10a:FOXN3,EGFP)z107] Models of Hyperglycemia

Karanth et al. (2016) could reach higher blood glucose levels by overexpressing a specific section of the first intron in FOXN3 gene by Tol2 transposon-mediated transgenesis. The gene carrier was determined to have a higher hepatic expression and downregulate in fasting conditions. Overexpressing of the named gene led to an elevated whole larval free glucose and higher adult FBS by hepatic gluconeogenic gene expression and suppression of mycb (human MYC ortholog, which is the 
expression stimulator of glucose consumer enzymes). Stable hyperglycemia in both larval stage and adulthood is a significant characteristic of this model.

$K_{A T P}$ Gain of Function ( $\left.K_{A T P}-G O F\right)$ Model of Hyperglycemia $\mathrm{K}_{\mathrm{ATP}}$ channels in $\beta$-cells control membrane excitability by glucose stimulated insulin secretion (Ashcroft and Rorsman, 1990). The channel is expressed in $\beta$-cells of zebrafish with similar functionality to their mammalian orthologs as well (Emfinger et al., 2017). In the following study, Emfinger et al. (2019) produced higher blood glucose levels by making gainof-function mutations in ATP dependent potassium channels of islet $\beta$-cells of zebrafish. These fish showed a slow growth and deficient glucose-induced calcium response, too. They used Tol2 transposase insertion to express cytosolic gCAMP6s.

\section{Zebrafish Zinc Finger Nuclease (ZFN) Models of T2DM \\ Type 2 Deiodinase (DIO2) Knockout Model of \\ Hyperglycemia}

In previous studies, it has been shown that DIO2 polymorphism is correlated with an increased FBS and insulin levels, insulin resistance, and susceptibility to diabetes (Canani et al., 2005; Dora et al., 2010). They developed two group of zebrafish DIO2 knockdown. The first and the second group were 6-9 and 18-24 months old, respectively. The knockout made the younger group hyperglycemic up to 1-year-old, accompanied with an increase in insulin and glucagon levels and reduction of insulin receptors on skeletal muscle. Older group showed a reduction in the glucagon receptors, glucose transporters, and G6PD. and were normoglycemic unlike the younger group (Houbrechts et al., 2019).

\section{Zebrafish CRISPR Models of Hyperglycemia} Multiplex Conditional Mutagenesis Model of Hyperglycemia Yin et al. (2015) produced hypopigmentation and defects of glucose hemostasis by the inactivation of insulin receptors (insra and insrb) and tyrosinase (tyr) genes, simultaneously. They also targeted ascl1 gene by sgRNAs injection to retinas and revealed a decrease in the number of proliferative cells after exposure to constant, high-intensity light. This model showed a lower FBS, insulin resistance, and post-prandial hyperglycemia eventually.

\section{Leptin Receptor Mutation Model of Hyperglycemia}

Leptin is a primary adipostatic factor produced by adipocytes in proportion to adipose mass in mammals. Lack of leptin receptors in mice produces obesity, hyperphagia, hyperinsulinemia, and diabetes (Halaas et al., 1995). Unlike mammals that express leptin receptor in adipose tissue mostly, fish highest expression takes place in the brain, white muscle, liver, and ovaries than adipose tissue (Kurokawa et al., 2005; Rønnestad et al., 2010). Proposed model by Michel et al. (2016) exhibited how leptin receptor signaling effects glucose homeostasis in zebrafish. They showed that mutagenesis of lepr and lepa, but not lepb genes exhibited increased $\beta$-cell number and hyperinsulinemia, hyperglucagonemia, and diabetes symptoms in larval stages.
They also investigated the possible effects in adulthood but did not find an elevated FBS.

\section{Pdx1 Gene Knockout Model of Hyperglycemia}

Pancreatic and duodenal homeobox $1(\mathrm{Pdx} 1)$ is essential for pancreas development and $\beta$-cell function (Fujimoto et al., 2009). Homozygous absence of PDX1 gene alleles is the indicator of early onset of T2DM (MODY4), but partial functionality of PDX1 gene increases the risk of T2DM occurrence (Staffers et al., 1997; Macfarlane et al., 1999; Weng et al., 2001).

In a study, it has been shown that CRISPR/Cas9-mediated gene knockout of pdxl gene in zebrafish is followed by retinopathic symptoms and post-prandial hyperglycemia (Wiggenhauser et al., 2020). This study is considered in the same category within Tables 2, 4 as the PDX1 gene knockdown model of hyperglycemia.

\section{MODY Gene Mutation Model of Hyperglycemia}

In a study by Mathews and Gustafsson (2019), the effect of common anti-diabetic drug tolbutamide on five major orthologs of human MODY related genes (gck, hnfla, hnflba, hnflbb, and pdx1) in zebrafish was assessed. They showed that tolbutamide intervention ameliorated induced a hyperglycemic state significantly. A mixture of high cholesterol diet (4\%) and immersion in glucose solution (3\%) from 5 to $9 \mathrm{dpf}$ were performed to challenge zebrafish larvae metabolically. More investigations on these mutations solely or in combination are required to assess T2DM characteristics thoroughly.

\section{Aldh3a1 Gene Knockout Model of Hyperglycemia}

Methylglyoxal (MG) is the major precursor of advanced glycation end products (AGEs) (Thornalley, 2008) which is degraded by glyoxalase system existing in the cytosol of mammalian cells (Rabbani and Thornalley, 2011). MG can also be degraded by aldo-keto-reductase and aldehyde dehydrogenase (ALDH) (Vander Jagt and Hunsaker, 2003). ALDH 3 families, member A1 (Aldh3a1) generally oxidizes lipid peroxidation aldehydes to carboxylic acids (Pappa et al., 2005). The gene is available in human, mouse, and zebrafish. In zebrafish, the gene shares $61.6 \%$ to human ALDH3A1 (Lou et al., 2020). Lou et al. (2020) revealed that aldh3a1-/- knockout in zebrafish is accompanied with an increased whole larval glucose, retinal vasodilatory alterations, and generally impaired glucose metabolism. They also showed a correlation between HbAlc increase and 4-hydroxynonenal (4HNE). This specific mutant hyperglycemic state was amplified by pdx1 gene silenced mutant and achieved a higher level of free larval glucose accordingly (Lou et al., 2020).

\section{G Protein-Coupled Receptor 27 (Gpr27) Knockout Model of Hyperglycemia}

Gpr family is well-conserved among vertebrates (Matsumoto et al., 2000). Among the family members, Gpr27 has shown to be expressed mostly in brain tissue and in several tissues like pancreas, skeletal muscle, and adipose tissue (Lonsdale et al., 2013). It has been revealed that the knockdown of Gpr27 in mouse pancreas caused a declination in insulin promotor activity 
(Ku et al., 2012). Knock out of the mentioned gene in zebrafish showed consistent results with the mammalian model. The fish did not show high FBS with normal diet, but a significant increase with a high fat diet, as we see in human T2DM state. The fish were also resistant to insulin injection, suggesting insulin resistance condition and a solid model for subsequent studies of T2DM (Nath et al., 2020).

\section{Glyoxalase1 (glo1 ${ }^{-/}$) Knockout Model of Hyperglycemia}

In a study by Lodd et al. (2019), permanent knockout of glyoxalase 1 using CRISPR/Cas9 was performed in order to evaluate long-term effects of the mentioned gene on glucose metabolism and the vascular system in juvenile and adult stages of zebrafish. The knockout model showed increased MG concentrations in the tissue, temporary increased post-prandial glucose, insulin resistance symptoms (p70-S6 kinase activation upregulation), impaired glucose tolerance, and increased retinal blood vessel sprouting after overfeeding suggesting retinopathic susceptibility. The remarkable point of the model is that (glo1 $1^{-/}$) knockout zebrafish are normoglycemic in the fasting condition but also show slower glucose homeostasis after feeding (Lodd et al., 2019). Although the model does not show persistent hyperglycemia and is dependent on overfeeding to show some symptoms, it can potentially be considered as the most wellstudied model to study T2DM in zebrafish so far.

\section{Morpholino Injection Models of Hyperglycemia PDX1 Gene Knockdown Model of Hyperglycemia}

Kimmel et al. (2015) could achieve a persistent hyperglycemic state in zebrafish by pdx1 gene knockdown utilizing morpholino injection. The model showed reduced $\beta$-cell number and insulin levels resulting in a persistent hyperglycemic state. Hyperglycemic state was consistent before feeding started all the way to adult stage. $\beta$-cells susceptibility of pdx1 mutants was revealed while larvae were exposed to a high fat diet. Despite revealing persistent hyperglycemia as a notable benefit, not revealing insulin resistance and decrease of $\beta$-cell numbers may incline the model to T1DM rather than T2DM, generally. This study is considered to be in the same category within following tables as the Pdx1 gene knockout model of hyperglycemia.

\section{Glucose Transporter 12 (GLUT12) Deficient Model of Hyperglycemia}

GLUT12 is generally expressed in insulin-sensitive tissues like heart, skeletal muscle, and adipose tissue. In a study by JiménezAmilburu et al. (2015), it is has been shown that the gene is on the same chromosme and mainly expressed in the same tissues as human and zebrafish preserves the same functionality of GLUT12 as human does. Morpholino knockdown of GLUT12 lead to hyperglycemia and insulin restance related genes disruption. Larvae showed a higher expression of GLUT12 in response to insulin injection and zebrafish larvae were also responsive to anti-diabetic drug, metformin.

\section{TALEN Mediated Models of Zebrafish Hyperglycemia Single Insra or Insrb Knockout Model of Hyperglycemia}

The insr is considered as a member of the tyrosine kinase receptor subfamily (De Meyts et al., 2008). It has been shown that the targeted disruption of insr gene is followed by neonatal lethality in mice. A 1,000-fold increase in glucose levels after normal feeding showed the seriousness of insr gene in glucose metabolism (Joshi et al., 1996). Unlike humans, zebrafish owns a duplication of insr gene generally referred as insra and insrb. Both revealed to be homologous to human insr gene by 68.3 and 65.1\% similarity (Toyoshima et al., 2008). A double knockout of insra and insrb yielded zebrafish death by $16 \mathrm{dpf}$ that was a confirmation to the mouse model study (Yang et al., 2017).

In a subsequent study by Yang et al. (2018) it has been shown that single insra or insrb knockout models of zebrafish showed higher blood glucose, post-prandial hyperglycemia, and increased weight gaining compared to the control group, while being viable unlike the double knockout model. These findings suggest this model to be an interesting model of diabetes research in zebrafish.

\section{METHODS OF MODEL VERIFICATION}

A verity of procedures is performed in order to verify hyperglycemic models as T2DM. Most common and acceptable ones are listed below.

\section{Hyperglycemic Outcome}

In human, high fasting blood glucose is usually the first indicator of T2DM existence and a clue to further investigations. In the reviewed studies, fasting blood glucose elevation (Gleeson et al., 2007; Connaughton et al., 2016), post-high content diet feeding blood glucose elevation (Yang et al., 2018), post-prandial glucose elevation (Nath et al., 2020), or whole larval glucose elevation (Karanth et al., 2016) are reported as the primary indicator of T2DM existence possibility.

Studies of zebrafish diabetes model can be categorized as adult and larval stage studies. Unlike adult stage, larval stage study of diabetes is limited due to the lack of blood. The suggested solution is homogenizing the larvae and using colorimetric assays to determine whole larval glucose. For adult stage, there are different methods of blood sampling and measuring glucose including tail ablation (Gleeson et al., 2007), decapitation (Eames et al., 2010), blood collection from dorsal aorta (Jagadeeswaran et al., 1999), and cardiac puncture (Moss et al., 2009). Procedure of repetitive non-lethal blood sampling is developed, which sure is a more ethical way of performing such tests (Zang et al., 2013).

\section{Insulin Resistance Test}

Insulin resistance is considered as one of the main symptoms of T2DM. In order to show insulin resistance, different approaches were suggested, such as measuring insulin (Meng et al., 2017), measuring insulin receptors (Houbrechts et al., 2019), measuring MG (Moraru et al., 2018), measuring related mediators (Nath et al., 2020), and insulin injection (Connaughton et al., 2016).

\section{Glucose Tolerance Test (GTT)}

This test is based on glucose intolerance and can be used as a confirmation test of T2DM model for zebrafish. This test is done in both intraperitoneal and oral forms for adult zebrafish (Kinkel et al., 2010). Due to the lack of blood in the larval stages of zebrafish life, gene expression assays are utilized to assess 
related genes, such as GLUT (Jiménez-Amilburu et al., 2015) or post-prandial hyperglycemia (Lodd et al., 2019) as an indicator of T2DM.

\section{HbA1c Alternatives Assay}

$\mathrm{HbAlc}$ in human is considered as a precise marker of diabetes. It is a glycated form of hemoglobin that increases in a hyperglycemic state. Therefore, it can be used as an important verification of diabetes existence (Mostafa et al., 2010). It is possible to extract fructosamine from the eyes of zebrafish and consider its increase as an upregulation of non-enzymatic glycation of proteins and diabetes (Armbruster, 1987; Capiotti et al., 2014). Other compounds, such as 4-hydroxynonenal (4HNE) (Lou et al., 2020) and MG (Lodd et al., 2019) are proposed as indicators, too.

\section{Anti-diabetic Drug Responsiveness Test}

Another method to verify the generated model is to use antidiabetic drug assessing. This method ensures the existence of the same metabolic pathways as humans, which through drugs can be effective. Glimepiride, metformin (Capiotti et al., 2014), tolbutamide (Mathews and Gustafsson, 2019), and pioglitazone (Wang et al., 1998) are proposed in this segment and can effect glucose metabolism by different mechanisms.

\section{Withdrawal of Inducer Assay/Maintaining Stable Hyperglycemia Overtime}

Due to different mechanisms of compatibility to a newer condition, inducing persistent hyperglycemic state is challenging in zebrafish. In different studies, after getting a hyperglycemic state, the inducer is removed and zebrafish is monitored to see how long it takes to get normoglycemic again. The longer the period, the better the induction method (Capiotti et al., 2014). Also, in some genetic studies like 2.5.1.2 method (Karanth et al., 2016) and 2.5.1.3 method (Emfinger et al., 2019), it has been shown that the proposed model can maintain an inert hyperglycemia over long periods of time (both larval and adult stage), promoting these mutant lines to valuable models of hyperglycemic state researches.

\section{Gene Expression Assay/Glucose Homeostasis Enzyme Assay}

Glucose homeostasis includes an extensive number of enzymes and factors. It is possible to confirm a model by key enzymes involving related pathways. Insulin signaling pathway-related genes, glycolysis-related genes, gluconeogenesis-related genes (Yang et al., 2018), insulin resistance related genes, and glucose transporters (Jiménez-Amilburu et al., 2015) are proposed to assess and interpret the yielded state thoroughly.

\section{High Content Diet/High Content Water Immersion Challenge}

In some studies, it has been suggested to challenge zebrafish after the induction period with food intake or immersion in high content water and determine if there is post-prandial diabetic like symptoms in comparison to a control group. High content diets, such as high calorie diet (Maddison et al., 2015), high carbohydrate diet (Yang et al., 2018), high fat diet (high cholesterol diet) (Kimmel et al., 2015; Nath et al., 2020), high cholesterol water immersion (Yin et al., 2015), or a combination of these (Mathews and Gustafsson, 2019) are proposed to see how much resemblance to human diabetic state is produced as a result of a hyperglycemia inducer agent.

\section{DISCUSSION}

Scientists have preferred rodents for diabetes modeling so far. Despite their physiological and biochemical advantages, they also have limitations. The zebrafish model has recently attracted much attention for metabolic and genetic studies. Also for diabetes studies, it represents major similarities to humans. Different approaches were suggested in order to study diabetes. Different approaches for induction of T2DM have been developed including glucose-induced models, diet based methods, chemical methods, genetic methods, and hybrid methods. In 2007, a study of T2DM by modeling in zebrafish was officially initiated (Gleeson et al., 2007). The idea of using glucose in the article was followed by next studies, too. These studies suggest practical and feasible models for studying genetic and physiological pathways involving the occurrence of diabetic symptoms. Obesity induced diabetes is favorable for studies of lipid metabolism in correlation of diabetic syndrome. Combination of these two approaches comes to another model that is proposed to study vascular disorders. The model represents high similarity to human disorders by being responsive to anti-diabetic compounds.

Chemicals penetrate to human body unintentionally and create a variety of side effects. Bisphenol, as a highly usable industrial chemical, was confirmed to produce diabetic symptoms in mice. In zebrafish, two different studies in larval and adult stages imply that this chemical can be used as a suitable diabetogenic reagent. They were also successful to target diabetes related genes in zebrafish and produce persistent hyperglycemia as well. Non-genetic means of hyperglycemia induction can be time consuming in comparison to genetic means. In contrast, they can be easily attained, need far less expensive facility to produce and maintain, and require less expertise to induce. Overall, the best method by our developed scoring table between non-genetic-induced zebrafish model of T2DM was the obesity model of hyperglycemia (Zang et al., 2017).

Initially, it is worth noting that genetic models gain higher scores on average. In this segment, although PDX1 gene knockdown/knockout (Kimmel et al., 2015; Wiggenhauser et al., 2020) gains a high score of eight, this does not reveal insulin resistance symptoms, making this model better suited for studying T1DM (Saberzadeh-Ardestani et al., 2018). The overall best model also lies among the genetic models. The 2.5.3.7 model by Lodd et al. (2019) is a well-studied mutant line of zebrafish for further study of T2DM. Of course, the model is accompanied with major drawbacks like being dependent on overfeeding to manifest T2DM symptoms or not assessing insulin resistance directly, however, it is the best evaluated model of hyperglycemia referred as T2DM in zebrafish overall. 
Moreover, this systematic review article introduced eight procedures that have been exploited in order to verify hyperglycemic models as T2DM. Considering using larval or adult model, various evaluation tests have been used in T2DM zebrafish models. Furthermore, for selecting the appropriate tests, the types of the models of T2DM, non-geneticinduced zebrafish model, and/or genetic-induced zebrafish model must be considered. These methods are within good and bad prospects. They should be utilized by consideration of study purposes, facility, and related professional experiences of researchers.

\section{FUTURE INSIGHTS}

All the efforts are aimed to find the absolute pathophysiology of diabetes mellitus and propose a definitive cure. Animal modeling is still the leading resembling platform to study diseases and cures. As we have seen in this systematic review, zebrafish has served as a valuable model due to its exceptional characteristics. Different models are summoned, reviewed, and compared with each other and human as well. All models reveal strengths and weaknesses. It is possible to design and score new models of zebrafish with the current scoring system. Due to the

\section{REFERENCES}

Armbruster, D. A. (1987). Fructosamine: structure, analysis, and clinical usefulness. Clin. Chem. 33, 2153-2163. doi: 10.1093/clinchem/33.12.2153

Ashcroft, F. M., and Rorsman, P. (1990). ATP-sensitive K+ channels: a link between B-cell metabolism and insulin secretion. Biochem. Soc. Trans. 18, 109-111. doi: 10.1042/bst0180109

Barbazuk, W. B., Korf, I., Kadavi, C., Heyen, J., Tate, S., Wun, E., et al. (2000). The syntenic relationship of the zebrafish and human genomes. Genome Res. 10, 1351-1358. doi: 10.1101/gr.144700

Canani, L. H., Capp, C., Dora, J. M., Souza Meyer, E. L., Wagner, M. S., Harney, J. W., et al. (2005). The type 2 deiodinase A/G (Thr92Ala) polymorphism is associated with decreased enzyme velocity and increased insulin resistance in patients with type 2 diabetes mellitus. J. Clin. Endocrinol. Metab. 90, 3472-3478. doi: 10.1210/jc.2004-1977

Capiotti, K. M., Antonioli, R., Kist, L. W., Bogo, M. R., Bonan, C. D., and Da Silva, R. S. (2014). Persistent impaired glucose metabolism in a zebrafish hyperglycemia model. Compar. Biochem. Physiol. B Biochem. Mol. Biol. 171, 58-65. doi: 10.1016/j.cbpb.2014.03.005

Carnovali, M., Luzi, L., Banfi, G., and Mariotti, M. (2016). Chronic hyperglycemia affects bone metabolism in adult zebrafish scale model. Endocrine 54, 808-817. doi: 10.1007/s12020-016-1106-3

Cong, L., Ran, F. A., Cox, D., Lin, S., Barretto, R., Habib, N., et al. (2013). Multiplex genome engineering using CRISPR/Cas systems. Science 339, 819-823. doi: 10.1126/science.1231143

Connaughton, V. P., Baker, C., Fonde, L., Gerardi, E., and Slack, C. (2016). Alternate immersion in an external glucose solution differentially affects blood sugar values in older versus younger zebrafish adults. Zebrafish 13, 87-94. doi: $10.1089 /$ zeb.2015.1155

Cox, M. E., and Edelman, D. (2009). Tests for screening and diagnosis of type 2 diabetes. Clin. Diabetes 27, 132-138. doi: 10.2337/diaclin.27.4.132

De Meyts, P., Palsgaard, J., Sajid, W., Theede, A. M., and Aladdin, H. (2008). "Structural biology of insulin and IGF-1 receptors," in Biology of IGF-1: Its Interaction With Insulin in Health and Malignant States, Vol. 262, eds G. R. Bock and J. A. Goode (Gentofte: Wiley Online Library), 160-171. doi: 10.1002/0470869976.ch10

Dooley, K., and Zon, L. I. (2000). Zebrafish: a model system for the study of human disease. Curr. Opin. Genet. Dev. 10, 252-256. doi: 10.1016/S0959-437X(00)00074-5 development of new tools for genetic manipulation and disease induction, it is expected from the zebrafish model of T2DM to play a key role in attaining definitive cure and accelerate the research process considerably. In addition, integration of the current modeling of T2DM with new technologies, such as microfluidics by using zebrafish embryo, fish-on-a-chip, computational drug screening, and three-dimensional image analysis will facilitate for finding therapeutic approaches for this syndrome.

\section{AUTHOR CONTRIBUTIONS}

AS, MR, AK, YT, and AT conceived and designed the format of the manuscript. AS, MR, and AK drafted and edited the manuscript. AS and AT drew the tables. All authors reviewed the manuscript, contributed to the critical reading and discussion of the manuscript, read, and agreed to the published version of the manuscript.

\section{FUNDING}

This study was financially supported by the Bushehr University of Medical Sciences (grant number: 1053).

Dora, J. M., Machado, W. E., Rheinheimer, J., Crispim, D., and Maia, A. L. (2010). Association of the type 2 deiodinase Thr92Ala polymorphism with type 2 diabetes: case-control study and meta-analysis. Eur. J. Endocrinol. 163, 427-434. doi: 10.1530/EJE-10-0419

Doyon, Y., McCammon, J. M., Miller, J. C., Faraji, F., Ngo, C., Katibah, G. E., et al. (2008). Heritable targeted gene disruption in zebrafish using designed zinc-finger nucleases. Nat. Biotechnol. 26, 702-708. doi: 10.1038/nbt1409

Driever, W., Solnica-Krezel, L., Schier, A. F., Neuhauss, S. C. F., Malicki, J., Stemple, D. L., et al. (1996). A genetic screen for mutations affecting embryogenesis in zebrafish. Development 123, 37-46.

Eames, S. C., Philipson, L. H., Prince, V. E., and Kinkel, M. D. (2010). Blood sugar measurement in zebrafish reveals dynamics of glucose homeostasis. Zebrafish 7, 205-213. doi: 10.1089/zeb.2009.0640

Emfinger, C. H., Lorincz, R., Wang, Y., York, N. W., Singareddy, S. S., Ikle, J. M., et al. (2019). Beta-cell excitability and excitability-driven diabetes in adult Zebrafish islets. Physiol. Rep. 7:e14101. doi: 10.14814/phy2.14101

Emfinger, C. H., Welscher, A., Yan, Z., Wang, Y., Conway, H., Moss, J. B., et al. (2017). Expression and function of ATP-dependent potassium channels in zebrafish islet $\beta$-cells. R. Soc. Open Sci. 4:160808. doi: 10.1098/rsos.160808

Engel, H., Xiong, L., Reichenberger, M. A., Germann, G., Roth, C., and Hirche, C. (2019). Rodent models of diet-induced type 2 diabetes mellitus: a literature review and selection guide. Diabetes Metab. Syndr. Clin. Res. Rev. 13, 195-200. doi: 10.1016/j.dsx.2018.07.020

Farhadi, A., Vosough, M., Zhang, J. S., Tahamtani, Y., and Shahpasand, K. (2019). A possible neurodegeneration mechanism triggered by diabetes. Trends Endocrinol. Metab. 30, 692-700. doi: 10.1016/j.tem.2019.07.012

Fujimoto, K., Hanson, P. T., Tran, H., Ford, E. L., Han, Z., Johnson, J. D., et al. (2009). Autophagy regulates pancreatic beta cell death in response to Pdx1 deficiency and nutrient deprivation. J. Biol. Chem. 284, 27664-27673. doi: 10.1074/jbc.M109.041616

Gleeson, M., Connaughton, V., and Arneson, L. S. (2007). Induction of hyperglycaemia in zebrafish (Danio rerio) leads to morphological changes in the retina. Acta Diabetol. 44, 157-163. doi: 10.1007/s00592-007-0257-3

Grunwald, D. J., and Streisinger, G. (1992). Induction of recessive lethal and specific locus mutations in the zebrafish with ethyl nitrosourea. Genet. Res. 59, 103-116. doi: 10.1017/S0016672300030317

Haffter, P., Granato, M., Brand, M., Mullins, M. C., Hammerschmidt, M., Kane, D. A., et al. (1996). The identification of genes with unique and essential functions in the development of the zebrafish, Danio rerio. Development 123, 1-36. 
Hajizadeh, E., Tahamtani, Y., Shokrgozar, M. A., Heimberg, H., Heremans, Y., Ravassard, P., et al. (2014). Co-transplantation of VEGF-expressing human embryonic stem cell derived mesenchymal stem cells to enhance islet revascularization in diabetic nude mice. Int. J. Pediatr. 2, 56-56. doi: 10.22038/ijp.2014.2719

Hajizadeh-Saffar, E., Tahamtani, Y., Aghdami, N., Azadmanesh, K., HabibiAnbouhi, M., Heremans, Y., et al. (2015). Inducible VEGF expression by human embryonic stem cell-derived mesenchymal stromal cells reduces the minimal islet mass required to reverse diabetes. Sci. Rep. 5:9322. doi: 10.1038/srep09322

Halaas, J. L., Gajiwala, K. S., Maffei, M., Cohen, S. L., Chait, B. T., Rabinowitz, D., et al. (1995). Weight-reducing effects of the plasma protein encoded by the obese gene. Science 269, 543-546. doi: 10.1126/science.7624777

Houbrechts, A. M., Beckers, A., Vancamp, P., Sergeys, J., Gysemans, C., Mathieu, C., et al. (2019). Age-dependent changes in glucose homeostasis in male deiodinase type 2 knockout zebrafish. Endocrinology 160, 2759-2772. doi: 10.1210/en.2019-00445

Howe, K., Clark, M. D., Torroja, C. F., Torrance, J., Berthelot, C., Muffato, M., et al. (2013). The zebrafish reference genome sequence and its relationship to the human genome. Nature 496, 498-503. doi: 10.1038/nature12111

Hu, F. B., Manson, J. E., Stampfer, M. J., Colditz, G., Liu, S., Solomon, C. G., et al. (2001). Diet, lifestyle, and the risk of type 2 diabetes mellitus in women. N. Engl. J. Med. 345, 790-797. doi: 10.1056/NEJMoa010492

Jagadeeswaran, P., Sheehan, J., Craig, F., and Troyer, D. (1999). Identification and characterization of zebrafish thrombocytes. Br. J. Haematol. 107, 731-738. doi: 10.1046/j.1365-2141.1999.01763.x

Jiménez-Amilburu, V., Jong-Raadsen, S., Bakkers, J., Spaink, H. P., and MarínJuez, R. (2015). GLUT12 deficiency during early development results in heart failure and a diabetic phenotype in zebrafish. J. Endocrinol. 224, 1-15. doi: 10.1530/JOE-14-0539

Joshi, R. L., Lamothe, B., Cordonnier, N., Mesbah, K., Monthioux, E., Jami, J., et al. (1996). Targeted disruption of the insulin receptor gene in the mouse results in neonatal lethality. EMBO J. 15, 1542-1547. doi: 10.1002/j.1460-2075.1996.tb00498.x

Jung, S. H., Kim, Y. S., Lee, Y. R., and Kim, J. S. (2016). High glucose-induced changes in hyaloid-retinal vessels during early ocular development of zebrafish: a short-term animal model of diabetic retinopathy. Br. J. Pharmacol. 173, 15-26. doi: 10.1111/bph.13279

Junker, J. P., Noël, E. S., Guryev, V., Peterson, K. A., Shah, G., Huisken, J., et al. (2014). Genome-wide RNA tomography in the zebrafish embryo. Cell 159, 662-675. doi: 10.1016/j.cell.2014.09.038

Jurczyk, A., Roy, N., Bajwa, R., Gut, P., Lipson, K., Yang, C., et al. (2011). Dynamic glucoregulation and mammalian-like responses to metabolic and developmental disruption in zebrafish. Gen. Compar. Endocrinol. 170, 334-345. doi: 10.1016/j.ygcen.2010.10.010

Karanth, S., Zinkhan, E. K., Hill, J. T., Yost, H. J., and Schlegel, A. (2016). FOXN3 regulates hepatic glucose utilization. Cell Rep. 15, 2745-2755. doi: 10.1016/j.celrep.2016.05.056

Kimmel, C. B., Ballard, W. W., Kimmel, S. R., Ullmann, B., and Schilling, T. F. (1995). Stages of embryonic development of the zebrafish. Dev. Dyn. 203, 253-310. doi: 10.1002/aja.1002030302

Kimmel, R. A., Dobler, S., Schmitner, N., Walsen, T., Freudenblum, J., and Meyer, D. (2015). Diabetic pdxl-mutant zebrafish show conserved responses to nutrient overload and anti-glycemic treatment. Sci. Rep. 5:14241. doi: $10.1038 /$ srep 14241

Kinkel, M. D., Eames, S. C., Philipson, L. H., and Prince, V. E. (2010). Intraperitoneal injection into adult zebrafish. J. Vis. Exp. e2126. doi: $10.3791 / 2126$

Ku, G. M., Pappalardo, Z., Luo, C. C., German, M. S., and McManus, M. T. (2012). An sirna screen in pancreatic beta cells reveals a role for Gpr27 in insulin production. PLoS Genet. 8:e1002449. doi: 10.1371/journal.pgen.1002449

Kurokawa, T., Uji, S., and Suzuki, T. (2005). Identification of cDNA coding for a homologue to mammalian leptin from pufferfish, Takifugu rubripes. Peptides 26, 745-750. doi: 10.1016/j.peptides.2004.12.017

Kurup, S., and Bhonde, R. R. (2000). Combined effect of nicotinamide and streptozotocin on diabetic status in partially pancreatectomized adult BALB/c mice. Horm. Metab. Res. 32, 330-334. doi: 10.1055/s-2007-978646

Kwan, K. M., Fujimoto, E., Grabher, C., Mangum, B. D., Hardy, M. E., Campbell, D. S., et al. (2007). The Tol2kit: a multisite gateway-based construction
Kit for Tol2 transposon transgenesis constructs. Dev. Dyn. 236, 3088-3099. doi: 10.1002/dvdy.21343

Lakstygal, A. M., de Abreu, M. S., Lifanov, D. A., Wappler-Guzzetta, E. A., Serikuly, N., Alpsyshov, E. T., et al. (2019). Zebrafish models of diabetes-related CNS pathogenesis. Prog. Neuropsychopharmacol. Biol. Psychiatry 92, 48-58. doi: 10.1016/j.pnpbp.2018.11.016

Lodd, E., Wiggenhauser, L. M., Morgenstern, J., Fleming, T. H., Poschet, G., Büttner, M., et al. (2019). The combination of loss of glyoxalase1 and obesity results in hyperglycemia. JCI Insight 4:e126154. doi: 10.1172/jci.insight.126154

Lonsdale, J., Thomas, J., Salvatore, M., Phillips, R., Lo, E., Shad, S., et al. (2013). The genotype-tissue expression (GTEx) project. Nat. Genet. 45, 580-585. doi: $10.1038 /$ ng.2653

Lou, B., Boger, M., Bennewitz, K., Sticht, C., Kopf, S., Morgenstern, J., et al. (2020). Elevated 4-hydroxynonenal induces hyperglycaemia via Aldh3al loss in zebrafish and associates with diabetes progression in humans. Redox Biol. 37:101723. doi: 10.1016/j.redox.2020.101723

Macfarlane, W. M., Frayling, T. M., Ellard, S., Evans, J. C., Allen, L. I. S., Bulman, M. P., et al. (1999). Missense mutations in the insulin promoter factor-1 gene predispose to type 2 diabetes. J. Clin. Invest. 104, R33-R39. doi: 10.1172/JCI7449

Maddison, L. A., Joest, K. E., Kammeyer, R. M., and Chen, W. (2015). Skeletal muscle insulin resistance in Zebrafish induces alterations in $\beta$-cell number and glucose tolerance in an age- and diet-dependent manner. Am. J. Physiol. Endocrinol. Metab. 308, E662-E669. doi: 10.1152/ajpendo.00441.2014

Mathews, B. M., and Gustafsson, E. (2019). A Zebrafish Model System for Drug Screening in Diabetes. Available online at: diva-portal.org

Matsumoto, M., Saito, T., Takasaki, J., Kamohara, M., Sugimoto, T., Kobayashi, M., et al. (2000). An evolutionarily conserved G-protein coupled receptor family, SREB, expressed in the central nervous system. Biochem. Biophys. Res. Commun. 272, 576-582. doi: 10.1006/bbrc.2000.2829

Meng, X. H., Chen, B., and Zhang, J. P. (2017). Intracellular insulin and impaired autophagy in a zebrafish model and a cell model of type 2 diabetes. Int. J. Biol. Sci. 13, 985-995. doi: 10.7150/ijbs.19249

Michel, M., P.S. Page-McCaw, Chen, W., and Cone, R. D. (2016). Leptin signaling regulates glucose homeostasis, but not adipostasis, in the zebrafish. Proc. Natl. Acad. Sci. U.S.A. 113, 3084-3089. doi: 10.1073/pnas.1513212113

Miller, J. C., Tan, S., Qiao, G., Barlow, K. A., Wang, J., Xia, D. F., et al. (2011). A TALE nuclease architecture for efficient genome editing. Nat. Biotechnol. 29, 143-148. doi: 10.1038/nbt.1755

Mohammadi, H., Manouchehri, H., Changizi, R., Bootorabi, F., and Khorramizadeh, M. R. (2020). Concurrent metformin and silibinin therapy in diabetes: assessments in zebrafish (Danio rerio) animal model. J. Diabetes Metab. Disord. 19, 1233-1244. doi: 10.1007/s40200-020-00698-8

Moraru, A., Wiederstein, J., Pfaff, D., Fleming, T., Miller, A. K., Nawroth, P., et al. (2018). Elevated levels of the reactive metabolite methylglyoxal recapitulate progression of type 2 diabetes. Cell Metab. 27, 926-934.e8. doi: 10.1016/j.cmet.2018.02.003

Moss, J. B., Koustubhan, P., Greenman, M., Parsons, M. J., Walter, I., and Moss, L. G. (2009). Regeneration of the pancreas in adult zebrafish. Diabetes 58, 1844-1851. doi: 10.2337/db08-0628

Mostafa, S. A., Davies, M. J., Srinivasan, B. T., Carey, M. E., Webb, D., and Khunti, K. (2010). Should glycated haemoglobin (HbAlc) be used to detect people with type 2 diabetes mellitus and impaired glucose regulation? Postgrad. Med. J. 86, 656-662. doi: 10.1136/pgmj.2009.091215

Nasevicius, A., and Ekker, S. C. (2000). Effective targeted gene 'knockdown' in zebrafish. Nat. Genet. 26, 216-220. doi: 10.1038/79951

Nath, A. K., Ma, J., Chen, Z. Z., Li, Z., M.d.Vitery, C., Kelley, M. L., et al. (2020). Genetic deletion of gpr27 alters acylcarnitine metabolism, insulin sensitivity, and glucose homeostasis in zebrafish. FASEB J. 34, 1546-1557. doi: 10.1096/fj.201901466R

Nolte, H., Hölper, S., Housley, M. P., Islam, S., Piller, T., Konzer, A., et al. (2015). Dynamics of zebrafish fin regeneration using a pulsed SILAC approach. Proteomics 15, 739-751. doi: 10.1002/pmic.201400316

Oka, T., Nishimura, Y., Zang, L., Hirano, M., Shimada, Y., Wang, Z., et al. (2010). Diet-induced obesity in zebrafish shares common pathophysiological pathways with mammalian obesity. BMC Physiol. 10:21. doi: 10.1186/1472-6793-10-21

Pappa, A., Brown, D., Koutalos, Y., DeGregori, J., White, C., and Vasiliou, V. (2005). Human aldehyde dehydrogenase 3A1 inhibits proliferation and 
promotes survival of human corneal epithelial cells. J. Biol. Chem. 280, 27998-28006. doi: 10.1074/jbc.M503698200

Partridge, M., Vincent, A., Matthews, P., Puma, J., Stein, D., and Summerton, J. (1996). A simple method for delivering morpholino antisense oligos into the cytoplasm of cells. Antisense Nucleic Acid Drug Dev. 6, 169-175. doi: 10.1089/oli.1.1996.6.169

Phillips, J. B., and Westerfield, M. (2019). "Zebrafish as a model to understand human genetic diseases," in Zebrafish in Biomedical Research, eds S. C. Cartner, S. C. Farmer, M. L. Kent, J. S. Eisen, K. J. Guillemin, G. E. Sanders (Eugene, OR: Elsevier), 619-626. doi: 10.1016/B978-0-12-812431-4.00047-6

Pinhas-Hamiel, O., and Zeitler, P. (2005). The global spread of type 2 diabetes mellitus in children and adolescents. J. Pediatr. 146, 693-700. doi: 10.1016/j.jpeds.2004.12.042

Pourghadamyari, H., Rezaei, M., Basiri, M., Tahamtani, Y., Asgari, B., Hassani, S. N., et al. (2019). Generation of a transgenic zebrafish model for pancreatic beta cell regeneration. Galen Med. J. 8, 1056-1056. doi: 10.31661/gmj.v8i0.1056

Qi, L. S., Larson, M. H., Gilbert, L. A., Doudna, J. A., Weissman, J. S., Arkin, A. P., et al. (2013). Repurposing CRISPR as an RNA- $\gamma$ uided platform for sequence-specific control of gene expression. Cell 152, 1173-1183. doi: 10.1016/j.cell.2013.02.022

Rabbani, N., and Thornalley, P. J. (2011). Glyoxalase in diabetes, obesity and related disorders. Semin. Cell Dev. Biol. 22, 309-317. doi: 10.1016/.j.semcdb.2011.02.015

Robinson, R., Barathi, V. A., Chaurasia, S. S., Wong, T. Y., and Kern, T. S. (2012). Update on animal models of diabetic retinopathy: from molecular approaches to mice and higher mammals. Dis. Models Mech. 5, 444-456. doi: $10.1242 / \mathrm{dmm} .009597$

Rønnestad, I., Nilsen, T. O., Murashita, K., Angotzi, A. R., Gamst Moen, A. G., Stefansson, S. O., et al. (2010). Leptin and leptin receptor genes in Atlantic salmon: cloning, phylogeny, tissue distribution and expression correlated to long-term feeding status. Gen. Compar. Endocrinol. 168, 55-70. doi: 10.1016/j.ygcen.2010.04.010

Saberzadeh-Ardestani, B., Karamzadeh, R., Basiri, M., Hajizadeh-Saffar, E., Farhadi, A., Shapiro, A. M. J., et al. (2018). Type 1 diabetes mellitus: cellular and molecular pathophysiology at a glance. Cell J. 20, 294-301. doi: $10.22074 /$ celli.2018.5513

Scherer, P. E. (2006). Adipose tissue: from lipid storage compartment to endocrine organ. Diabetes 55, 1537-1545. doi: 10.2337/db06-0263

Schlegel, A., and Stainier, D. Y. R. (2007). Lessons from "lower" organisms: what worms, flies, and zebrafish can teach US about human energy metabolism. PLoS Genet. 3:e0030199. doi: 10.1371/journal.pgen.0030199

Serbedzija, G. N., Flynn, E., and Willett, C. E. (1999). Zebrafish angiogenesis: a new model for drug screening. Angiogenesis 3, 353-359. doi: 10.1023/A:1026598300052

Sheikhpour, R., and Khoradmehr, A. (2014). New insights into the effect of diabetes and obesity in Alzheimer's disease. Iran. J. Diabetes Obes. 6, 41-45.

Singh, A., Castillo, H. A., Brown, J., Kaslin, J., Dwyer, K. M., and Gibert, Y. (2019). High glucose levels affect retinal patterning during zebrafish embryogenesis. Sci. Rep. 9:4121. doi: 10.1038/s41598-019-41009-3

Staffers, D. A., Ferrer, J., Clarke, W. L., and Habener, J. F. (1997). Early-onset type-ll diabetes mellitus (Mody4) linked to ipf1. Nat. Genet. 17, 139-139. doi: 10.1038/ng1097-138

Streisinger, G., Walker, C., Dower, N., Knauber, D., and Singer, F. (1981). Production of clones of homozygous diploid zebra fish (Brachydanio rerio). Nature 291, 293-296. doi: 10.1038/291293a0

Surwit, R. S., Kuhn, C. M., Cochrane, C., McCubbin, J. A., and Feinglos, M. N. (1988). Diet-induced type II diabetes in C57BL/6J mice. Diabetes 37, 1163-1167. doi: $10.2337 /$ diab.37.9.1163

Tamadon, A., Hu, W., Cui, P., Ma, T., Tong, X., Zhang, F., et al. (2018). How to choose the suitable animal model of polycystic ovary syndrome? Tradit. Med. Modern Med. 01, 95-113. doi: 10.1142/S2575900018300047

Thornalley, P. J. (2008). Protein and nucleotide damage by glyoxal and methylglyoxal in physiological systems-role in ageing and disease. Drug Metabol. Drug Interact. 23, 125-150. doi: 10.1515/DMDI.2008.23.1-2.125

Tobey, T. A., Mondon, C. E., Zavaroni, I., and Reaven, G. M. (1982). Mechanism of insulin resistance in fructose-fed rats. Metabolism 31, 608-612. doi: 10.1016/0026-0495(82)90100-7
Toyoshima, Y., Monson, C., Duan, C., Wu, Y., Gao, C., Yakar, S., et al. (2008). The role of insulin receptor signaling in zebrafish embryogenesis. Endocrinology 149, 5996-6005. doi: 10.1210/en.2008-0329

Tripathi, V., and Verma, J. (2014). Different models used to induce diabetes: a comprehensive review. Int. J. Pharma. Pharma. Sci. 6, 29-32.

Vander Jagt, D. L., and Hunsaker, L. A. (2003). Methylglyoxal metabolism and diabetic complications: roles of aldose reductase, glyoxalase-I, betaine aldehyde dehydrogenase and 2-oxoaldehyde dehydrogenase. Chem. Biol. Interact. 143-144, 341-351. doi: 10.1016/S0009-2797(02)00212-0

Wang, H., Long, Q., Marty, S. D., Sassa, S., and Shuo, L. (1998). A zebrafish model for hepatoerythropoietic porphyria. Nat. Genet. 20, 239-243. doi: 10.1038/3041

Wang, J. J., Li, Y. J., Lai, K., Zhong, Q. M., Demin, K. A., Kalueff, A. V., et al. (2020). High-glucose/high-cholesterol diet in zebrafish evokes diabetic and affective pathogenesis: the role of peripheral and central inflammation, microglia and apoptosis. Prog. Neuropsychopharmacol. Biol. Psychiatry 96:109752. doi: 10.1016/j.pnpbp.2019.109752

Wang, Z., Mao, Y., Cui, T., Tang, D., and Wang, X. L. (2013). Impact of a combined high cholesterol diet and high glucose environment on vasculature. PLoS ONE 8:e81485. doi: 10.1371/journal.pone.0081485

Weng, J., Macfarlane, W. M., Lehto, M., Gu, H. F., Shepherd, L. M., Ivarsson, S. A., et al. (2001). Functional consequences of mutations in the MODY4 gene (IPF1) and coexistence with MODY3 mutations. Diabetologia 44, 249-258. doi: $10.1007 /$ s001250051608

Wiggenhauser, L. M., Qi, H., Stoll, S. J., Metzger, L., Bennewitz, K., Poschet, G., et al. (2020). Activation of retinal angiogenesis in hyperglycemic $\mathrm{pdx}^{-/-}$ zebrafish mutants. Diabetes 69, 1020-1031. doi: 10.2337/db19-0873

Yang, B., Zhai, G., Gong, Y., Su, J., Han, D., Yin, Z., et al. (2017). Depletion of insulin receptors leads to $\beta$-cell hyperplasia in zebrafish. Sci. Bull. 62, 486-492. doi: 10.1016/j.scib.2017.03.001

Yang, B. Y., Zhai, G., Gong, Y. L., Su, J. Z., Peng, X. Y., Shang, G. H., et al. (2018). Different physiological roles of insulin receptors in mediating nutrient metabolism in zebrafish. Am. J. Physiol. Endocrinol. Metab. 315, E38-E51. doi: 10.1152/ajpendo.00227.2017

Yin, L., Maddison, L. A., Li, M., Kara, N., Lafave, M. C., Varshney, G. K., et al. (2015). Multiplex conditional mutagenesis using transgenic expression of Cas9 and sgRNAs. Genetics 200, 431-441. doi: 10.1534/genetics.115.176917

Zang, L., Maddison, L. A., and Chen, W. (2018). Zebrafish as a model for obesity and diabetes. Front. Cell Dev. Biol. 6:91. doi: 10.3389/fcell.2018.00091

Zang, L., Shimada, Y., and Nishimura, N. (2017). Development of a novel zebrafish model for type 2 diabetes mellitus. Sci. Rep. 7:1461. doi: 10.1038/s41598-017-01432-w

Zang, L., Shimada, Y., Nishimura, Y., Tanaka, T., and Nishimura, N. (2013). A novel, reliable method for repeated blood collection from aquarium fish. Zebrafish 10, 425-432. doi: 10.1089/zeb.2012.0862

Zhang, M., Lv, X. Y., Li, J., Xu, Z. G., and Chen, L. (2008). The characterization of high-fat diet and multiple low-dose streptozotocin induced type 2 diabetes rat model. Exp. Diabetes Res. 2008:704045. doi: 10.1155/2008/704045

Zhao, F., Jiang, G., Wei, P., Wang, H., and Ru, S. (2018b). Bisphenol S exposure impairs glucose homeostasis in male zebrafish (Danio rerio). Ecotoxicol. Environ. Saf. 147, 794-802. doi: 10.1016/j.ecoenv.2017.09.048

Zhao, F., Wang, H., Wei, P., Jiang, G., Wang, W., Zhang, X., et al. (2018a). Impairment of bisphenol $\mathrm{F}$ on the glucose metabolism of zebrafish larvae. Ecotoxicol. Environ. Saf. 165, 386-392. doi: 10.1016/j.ecoenv.2018.09.017

Zon, L. I., and Peterson, R. T. (2005). In vivo drug discovery in the zebrafish. Nat. Rev. Drug Discov. 4, 35-44. doi: 10.1038/nrd1606

Conflict of Interest: The authors declare that the research was conducted in the absence of any commercial or financial relationships that could be construed as a potential conflict of interest.

Copyright (c) 2021 Salehpour, Rezaei, Khoradmehr, Tahamtani and Tamadon. This is an open-access article distributed under the terms of the Creative Commons Attribution License (CC BY). The use, distribution or reproduction in other forums is permitted, provided the original author(s) and the copyright owner(s) are credited and that the original publication in this journal is cited, in accordance with accepted academic practice. No use, distribution or reproduction is permitted which does not comply with these terms. 